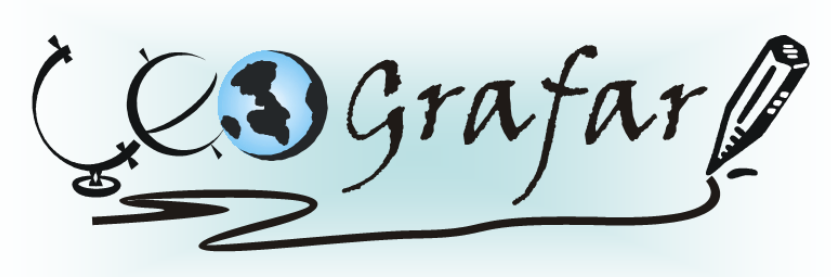

Revista Eletrônica do Programa de Pós-Graduação em Geografia - UFPR

\title{
A ESTRUTURA GEOECOLÓGICA DA PAISAGEM COMO SUBSÍDIO A ANÁLISE GEOAMBIENTAL NO MUNICÍPIO DE APUCARANA-PR
}

\author{
FERNANDO CÉSAR MANOSSO ${ }^{1}$
}

MARIA TERESA DE NÓBREGA ${ }^{2}$

\begin{abstract}
RESUMO: O conhecimento da estrutura geoecológica da paisagem e o seu funcionamento fornece importantes subsídios para a análise ambiental e o planejamento das atividades socioeconômicas de forma mais sustentável. Este trabalho apresenta as diferentes unidades de paisagens que compõem o território municipal de Apucarana. Foram identificadas sete unidades de paisagem, definidas a partir da análise integrada dos elementos relevo, litologia, solos e aspectos socioeconômicos. As vertentes típicas em cada unidade foram tomadas como referência para a definição da estrutura geoecológica (vertical e horizontal), formas de uso e ocupação atual e funcionamento. Foram identificadas sete unidades de paisagem representadas em um quadro e um mapa síntese que permitem uma visão mais ampla e integrada entre elas.
\end{abstract}

Palavras-Chave: Estrutura Geoecológica, Paisagem, Vertentes e Apucarana.

\begin{abstract}
The knowledge of the landscape geoecological structure and its functioning provides important data for the environmental analysis and the planning of socioeconomic activities in a more sustainable way. This work presents the different landscape units that make up the municipal territory of Apucarana. It was identified seven landscape units, defined from the integrated analysis of the factors: relief, lithology, soils and socioeconomic aspects. The typical strands in each unit were taken as reference for defining the geoecological structure (vertical and horizontal), forms of current use and occupation and operation. It was identified seven landscape units represented in a table and a summary map that allow a broader and integrated view of them.
\end{abstract}

Key-Words: Landscape, Structure Geoecological, Strands and Apucarana.

\section{INTRODUÇÃO}

Nas ultimas décadas, preocupações de ordem mundial têm sido direcionadas para alguns problemas ambientais como, por exemplo, o aquecimento global, as agressões à camada de ozônio e a crescente escassez de água potável. No entanto, além destes, existem outros que necessitam intervenções, ações e pesquisas em nível local, e que representam um grande passo na garantia da exploração e aproveitamento racional dos recursos.

\footnotetext{
${ }^{1}$ Doutorando em Geografia do Programa de Pós-Graduação em Geografia da Universidade Estadual de Maringá-PR - Bolsista CAPES.

${ }^{2}$ Professora Dra. do Departamento de Geografia da Universidade Estadual de Maringá-PR.

Contato: fmanosso@yahoo.com.br
} 
As ações e pesquisas em escalas locais são mais passíveis de aplicação, por este motivo foi selecionado o recorte político do município de Apucarana, situado na região Norte do estado do Paraná, cujo território é composto por vários compartimentos distintos de paisagem, dotados de um agrupamento de atributos próprios e um funcionamento particular que merecem melhor entendimento.

No município, observam-se paisagens reorganizadas em função das atuais condições político-sociais e econômicas, enquanto outras guardam vestígios de condições passadas, através de uma aparente resistência do setor rural frente ao modelo de exploração agrícola atual. Em alguns casos percebe-se que por trás dessa situação divergente estão associados fatos e fenômenos que geram potencialidades e limitações distintas, tornando certas áreas mais aptas ou menos aptas aos modelos de exploração atuais.

Os estudos integrados de paisagem, no âmbito da geografia física, contemplam esses aspectos, sobretudo aqueles que inserem as dinâmicas socioeconômicas sobre um plano de atributos e elementos físicos que, por sua vez, são dotados de funcionalidade própria no espaço e no tempo.

Frades (1994) interpreta o potencial ecológico das paisagens, representado pelas condições climáticas e características edáficas, como integrante do processo produtivo agrário e por isso também responsável pela organização das paisagens. O que vai ao encontro às afirmativas de Bolós (1992) quando indica a diversidade das paisagens rurais como fruto da forma de ocupação e exploração do território e em definitivo, do tratamento concedido aos recursos naturais. E que a diversidade espacial da paisagem rural se baseia igualmente nas diferentes formas de uso e exploração própria de cada cultura e nas características naturais climáticas e físicas das paisagens. Essa autora situa, a partir de uma concepção geossistêmica, o sistema agrário como uma interface entre os sistemas abiótico, biótico e sócio econômico.

Diversos trabalhos acadêmicos como os de Frades (1994), Rodriguez et al (1995), Espino (1995), Sheibe (1997), Ferreira (1997), Rodrigues (1998), Pellerin e Hellvin (1998), Santos et al (2000), Rossi e Queiroz Neto (2001), Pedrotti e Martinelli (2001), Carvalho e Braga (2001), Ruhoff (2002), Cavalheiro et al (2002), Ribeiro et al (2002), Buche (2003), Dias (2003), Freitas et al (2003), Marçal et al (2003), Valaski e Nucci (2007), Kröker (2007), Dias e Santos (2007), Deschamps (2004), Oliveira (2003), Peccioli Filho (2005) dentre outros buscam compreender e classificar as paisagens de forma integrada no intuito de identificar 
suas potencialidades, limitações e inclusive avaliar a estrutura geoecológica como suporte para atividades socioeconômicas, ambiental e socialmente responsáveis.

Como decorrência, através do diagnóstico da paisagem, onde são reconhecidos os seus elementos principais, sua estrutura e seu funcionamento, pode-se criar mecanismos mais hábeis para subsidiar o planejamento e as ações dos sistemas socioeconômicos que exploram o potencial ecológico dessa paisagem. A utilização do potencial ecológico carece muitas vezes de informação sobre o real comportamento do ambiente físico, o que geralmente se reverte em maiores custos na reprodução do capital e na maior degradação do ambiente.

A preocupação mais expressiva é delimitar as unidades sob uma ótica das suas qualidades físicas, como morfologia, estrutura, funcionamento, comportamento e evolução, além da ótica socioeconômica, que é determinada pelas decisões sócio-políticas, institucionais, organizacionais, econômicas, etc, formando, assim, um conjunto de atributos síntese pertinentes à classificação e delimitação das unidades.

No que se refere à delimitação, este é um processo muito abstrato, de difícil precisão e que se deve preocupar com as escalas de grandeza da interpretação, pois como menciona Ross (1991), não existe modificações bruscas de uma condição ambiental para outra, existindo sempre uma faixa de transição.

As unidades de paisagem também se organizam sobre o território em função de uma série de atributos temporais e espaciais que na maioria das vezes são de difícil delimitação e por isso, o método de abordagem integrada ou sistêmica procura associar o máximo possível de informações quantitativas e qualitativas do ambiente para, desta forma, poder sintetizar a organização das unidades homogêneas, dotadas de um comportamento e uma estrutura própria.

Estrutura esta que possui um funcionamento e uma variação horizontal e vertical, os quais deve-se interpretar de modo integrado.

A paisagem, de acordo com uma escala de grandeza, possui uma distribuição heterogênea ao longo da superfície, e por isso, considera-se que horizontalmente, a paisagem sofre diversas modificações de ordem morfológica, estrutural, litológica, pedológica, climática e geomorfológica, além da cobertura vegetal natural ou não e dos vários usos urbanos e agrários. 
A estrutura vertical da paisagem é definida pelos seus diversos elementos (a atmosfera, passando pela superfície edáfica, incidindo sobre a cobertura vegetal, as águas superficiais e sub-superficiais, chegando até a rocha mãe), que interagindo uns sobre os outros, em um dado local, são os responsáveis pela dinâmica natural da paisagem. A variação horizontal, por outro lado, é identificada e classificada através dos geofácies, que é, em termos gerais, resultante da reprodução espacial de uma dada estrutura vertical (BEROUCHACHVILI e BERTRAND, 1978).

São sobre estas estruturas geoecológicas superficiais verticais e horizontais que inferem as atividades antrópicas, influenciando fortemente pela produção social atuante o funcionamento das paisagens como um todo.

Nesse trabalho objetiva-se, portanto, apresentar a síntese do mosaico de paisagens identificadas ao longo do território do município de Apucarana, assim como a sua caracterização e dinâmica, tomando-se as vertentes típicas em cada unidade para, a partir delas, apresentar a sua estrutura geoecológica (vertical e horizontal), formas de uso e ocupação atual e funcionamento.

\section{MATERIAIS E MÉTODOS}

\section{Caracterização geral da área de estudo}

O município de Apucarana está localizado na região norte do estado do Paraná (Figura 1). A cidade foi instalada em 1944, por intermédio das ações da Companhia de Terras Norte do Paraná, desenvolvendo-se no contexto da expansão da agricultura cafeeira, proveniente do interior do estado de São Paulo, e na produção, beneficiamento e transporte deste produto.

Situado no Terceiro Planalto Paranaense, sobre um grande divisor de águas entre as bacias hidrográficas dos rios Tibagi a Leste, Ivaí ao Sul e Paranapanema ao Norte, o município de Apucarana apresenta altitudes compreendidas entre 750 e 860 metros ao longo deste interflúvio principal, até cotas inferiores a 500 metros, nas extremidades Leste, Oeste e Sul do município. O substrato geológico em toda a extensão é constituído por uma sucessão de derrames vulcânicos (rochas basálticas e andesi-basálticas, predominantemente), da Formação Serra Geral, Grupo São Bento. 
FIGURA 1. LOCALIZAÇÃO DA ÁREA DE ESTUDO

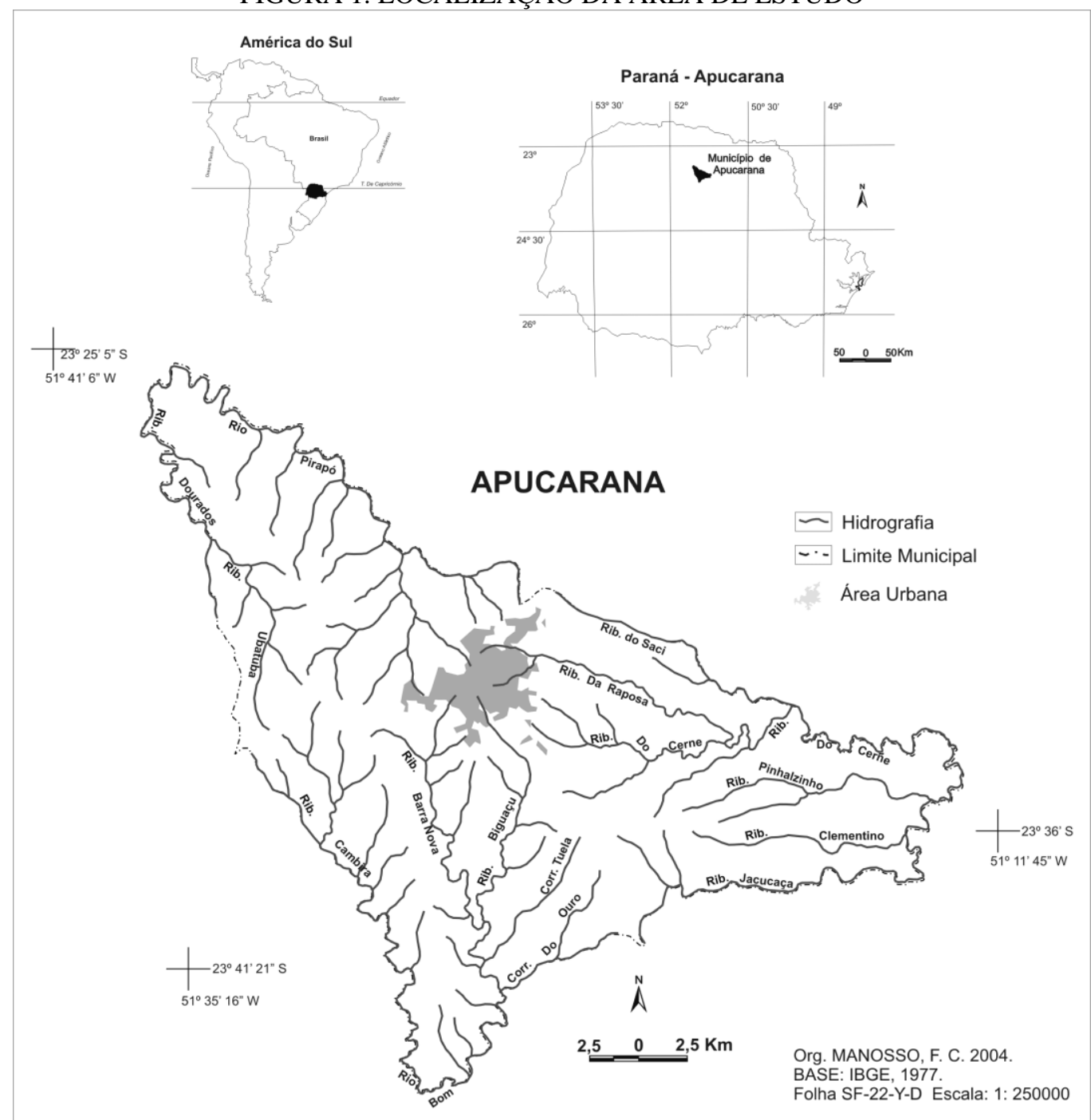

O clima é do tipo úmido mesotérmico, com pluviometria anual acumulada entre 1.500 e $1.700 \mathrm{~mm}$ e uma temperatura média anual de $20^{\circ} \mathrm{C}$ (Simepar, série de dados 1968 - 2002).

Esta configuração física reflete uma paisagem bastante diversificada, que possui como produtos agrícolas principais o milho, a soja, o trigo, o café, além da atividade pecuária, dentre outros cultivos de menor extensão como frutíferas (uva, caqui, abacate, etc).

\section{Metodologia}

Para alcançar os documentos síntese que aqui são apresentados, passou-se por diversas etapas, com aplicação e adaptação de vários métodos, além da própria revisão bibliográfica sobre o tema e sobre a área em estudo, conforme o Quadro 1. 
QUADRO 1. ETAPAS DA PESQUISA

\begin{tabular}{|c|c|}
\hline ETAPA & OBJETIVOS \\
\hline $\begin{array}{l}\text { - Adaptações Metodológicas } \\
\text { (Richard, 1975; 1989), } \\
\text { (Bertrand, 1872; 1978) e } \\
\text { (Monteiro, 1995; 2000) }\end{array}$ & $\begin{array}{l}\text { - Análise da Paisagem (Fundamentação teórico-metodológica) } \\
\text { - Construção dos Perfis Geoecológicos }\end{array}$ \\
\hline - Levantamento de Dados & $\begin{array}{l}\text { - Reconhecimento de Campo } \\
\text { - Dados socioeconômicos (economia, população, agricultura e } \\
\text { territoriais) } \\
\text { - Registro fotográfico } \\
\text { - Construção da Base Cartográfica (Clima, Solos, Hidrografia, } \\
\text { Hipsometria, Declividade, Uso do Solo, Imageamento por satélite e } \\
\text { Fotografias aéreas) } \\
\text { - Entrevistas }\end{array}$ \\
\hline $\begin{array}{l}\text { - Análise integrada da paisagem } \\
\text { e Tabulação de Dados }\end{array}$ & $\begin{array}{l}\text { - Agricultura e Pecuária; Economia; Sócio-espacialidade; } \\
\text { Representação Cartográfica. }\end{array}$ \\
\hline - Controle de Campo & $\begin{array}{l}\text { - Classificação e Delimitação das Unidades de Paisagem } \\
\text { - Caracterização e detalhamento das unidades } \\
\text { - Estrutura Geoecológica (Vertical e Horizontal) }\end{array}$ \\
\hline - Diagnóstico e Prognóstico & $\begin{array}{l}\text { - Documentos finais (quadro síntese e mapa síntese) } \\
\text { - Cruzamento e Sobreposição temática }\end{array}$ \\
\hline
\end{tabular}

\section{Materiais utilizados}

Documentos Cartográficos

- Mapa de Solos do Estado do Paraná (Ministério da Agricultura, Escala 1:300 000) 1971

- Folha Topográfica Escala 1:250 000 S-F-22-Y-D (1977)

- Imagem Landsat ETM+ (2000);

- Atlas do Estado do Paraná (1987)

- Fotografias Aéreas (COPEL, 1980) Escala 1:25 000

- Fotografias Aéreas (PARANACIDADE, 1996) Escala 1: 10000

Dados socioeconômicos

- Dados Municipais (EMATER-PR, SEAB, DERAL, PREFEITURA e IBGE)

- Censos Demográficos e Agropecuários (IBGE)

- Entrevistas junto a pioneiros da cidade

\section{Procedimentos}

De modo a alcançar as unidades de paisagem apresentadas a seguir, adotou-se o critério de cruzamento dos materiais cartográficos, junto a aferições de campo para se chegar à compartimentação das áreas definidas como unidades de paisagem do município de Apucarana. 
Os dados socioeconômicos, apesar de não possibilitar sua espacialização cartográfica, a classificação supervisionada pelo método MAXVER (Spring - INPE) apoiou a análise da distribuição do uso do solo e a comparação do mesmo, principalmente com os tipos de solo e declividades, assim como os dados adquiridos junto a órgãos especializados e entrevistas apoiaram o entendimento temporal da organização do espaço no município.

Após a definição da compartimentação das unidades de paisagem, diretamente no campo elegeu-se uma vertente típica de cada compartimento para detalhamento in locu, com levantamento planialtimétrico, algumas sondagens e aferições referentes ao uso, afloramentos rochosos, blocos, etc (Figuras 3 até 9).

\section{RESULTADOS}

\section{A compartimentação da paisagem}

A digitalização da base cartográfica em um banco de dados, somado as observações e controle de campo possibilitou sobrepor informações sobre as diferentes áreas e com isso a classificação das unidades de paisagens, conforme a Figura 2.

O mapa da compartimentação da área de estudo (Figura 2) objetiva delimitar as unidades de paisagem, caracterizadas por uma estrutura vertical e lateral particular. Essas unidades foram definidas a partir de análise integrada dos elementos relevo, litologia, solos e aspectos socioeconômicos, preferencialmente, tendo em vista o reconhecimento do potencial ecológico dos compartimentos e sua forma de utilização.

\section{Estrutura geoecológica dos compartimentos (unidades de paisagem)}

\section{Compartimento 1 - "Interflúvio Principal"}

O compartimento 1 compreende o topo do interflúvio principal e parte dos topos dos esporões secundários, com cotas altimétricas acima de 800 metros, e que correspondem, grosso modo, à porção central do município. Seus solos predominantes distribuem-se entre os LATOSSOLOS VERMELHOS Distroférricos e/ou Eutroférricos associados a um relevo de 
colinas amplas, vertentes convexas, onde domina uma agricultura mecanizada, de lavouras temporárias e os cafeeiros, que se concentram sobre as médias colinas nas margens da rodovia BR 376 (saída para Maringá) e nas vertentes de face norte.

FIGURA 2. COMPARTIMENTAÇÃO DO MUNICÍPIO E APUCARANA. C1-INTERFLÚVIO PRINCIPAL; C2- CABECEIRAS DO RIO PIRAPÓ; C2.A- PLATÔS EMBUTIDOS; C3- FOZ DO RIBEIRÃO DOURADOS; C4- COLINAS DO RIO BOM; C5- VALES DO SETOR SUL; C6- VALES DO SETOR LESTE; C7- COLINAS DO RIO DO CERNE.

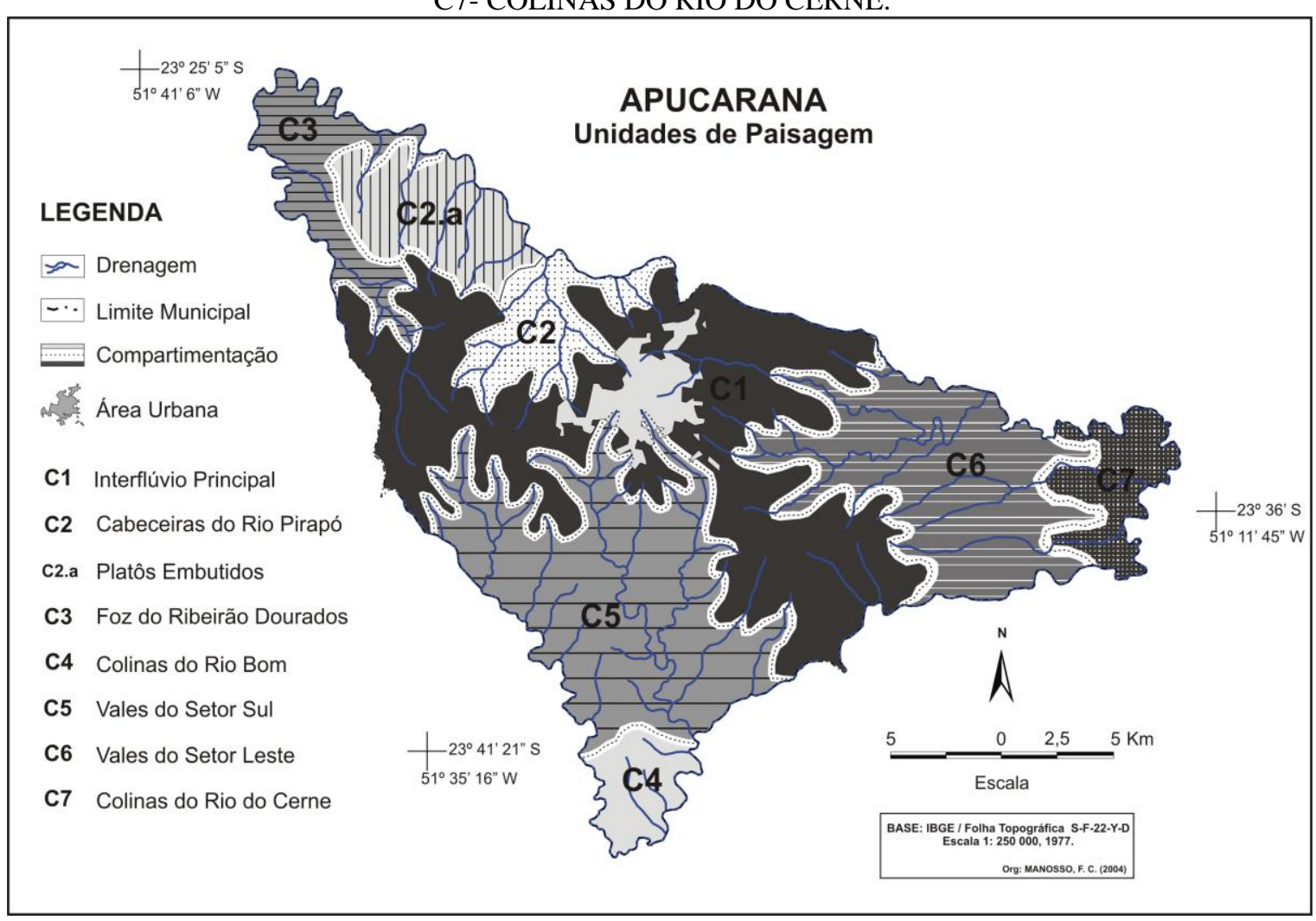

Esta área do interflúvio abriga as cabeceiras de drenagem dos pequenos cursos de água que se direcionam a outras partes do município. Como o núcleo urbano de Apucarana, assim como trechos das rodovias BR 369 e BR 376 se localizam nesta unidade, as condições hídricas dessas cabeceiras e dos cursos d'água estão sendo bastante afetadas pelo escoamento superficial de água, aumentado e concentrado pela urbanização, a montante.

Esta unidade é a mais elevada, passando lateralmente para unidades mais baixas produzidas pelo entalhe da drenagem e que se apresentam como áreas de vales encaixados (C2, C5 e C6). Essa passagem é marcada por vertentes com declividades acentuadas, rupturas freqüentes, afloramentos de rocha ou exposição de blocos. Essas condições físicas impõem 
barreiras para a expansão das frentes de ocupação urbana e industrial que se encontram no compartimento de topo.

No entanto, nos últimos anos a ocupação destas áreas tem sido intensa, o que têm propiciado uma série de problemas ambientais.

Geralmente ocorre a distribuição do LATOSSOLO VERMELHO Distroférrico sobre o topo estendendo-se até a média vertente e o NITOSSOLO VERMELHO Eutroférrico a partir da média vertente até o sopé, na área maior declive.

No caso desta unidade onde as vertentes não apresentam rupturas de declive acentuadas ou declividades muito elevadas, o nível do lençol freático (livre) geralmente acompanha a camada de alteração no período úmido e pode estar entre as fraturas da rocha em períodos de estiagem, como julho ou agosto.

Ocupadas em sua maior parte por cultivos temporários, as vertentes convexas do Compartimento 1 favorecem aos sistemas agrários mecanizados voltados para produtos como o trigo, milho e soja (Figura 3).

FIGURA 3. 1- ROCHAS VULCÂNICAS ANDESI-BASÁLTICAS (PERÍODO JURO-CRETÁCEO FORMAÇÃO SERRA GERAL, GRUPO SÃO BENTO); 2- LATOSSOLO VERMELHO DISTROFÉRRICO; 3- NITOSSOLO VERMELHO EUTROFÉRRICO; 4- NÍVEL DE ALTERAÇÃO (ALTERITA); 5- NÍVEL DE BASE LOCAL; 6- CULTURAS TEMPORÁRIAS (TRIGO EM ESTÁGIO INICIAL); 7- SUPERFÍCIE PIEZOMÉTRICA; 8- VEGETAÇÃO CILIAR.

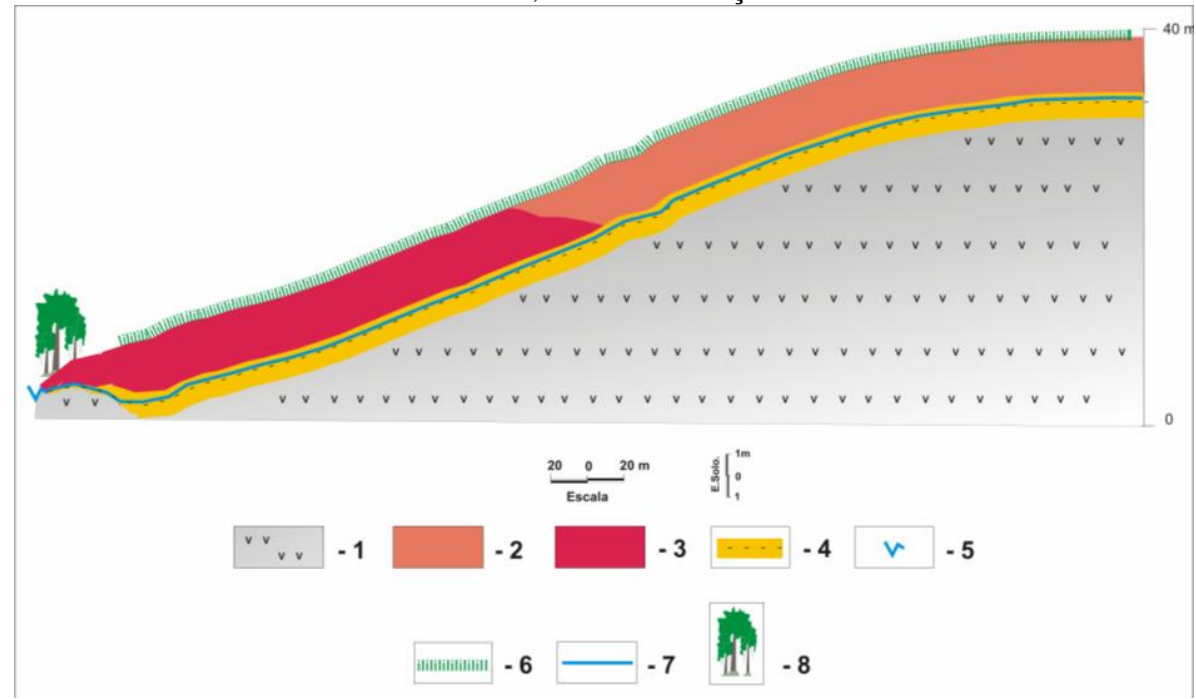

Org. MANOSSO, F. C. (2004) 


\section{Compartimento 2 - "Cabeceiras do Rio Pirapó"}

Esta unidade engloba uma pequena porção da região noroeste do município, representada pela cabeceira do rio Pirapó e está subdividido em compartimento 2.a e 2.b que possuem declividades elevadas no alto curso de seus tributários, vales encaixados, com vertentes que se desdobram em "patamares", delineados pelas rupturas convexas, côncavas, e setores retilíneos de vertentes. Ao longo dessas vertentes predomina o NITOSSOLO VERMELHO Eutroférrico ocorrendo, também, o NEOSSOLO LITÓLICO em alguns setores, associados freqüentemente às rupturas marcadas do relevo.

Na passagem do compartimento 1 para o compartimento 2, o entalhe dos pequenos cursos d'água formadores do rio Pirapó, próximo às suas cabeceiras, modelam um conjunto de pequenas colinas convexas embutidas em reentrâncias do interflúvio principal (C1).

Os usos estabelecidos nesta área estão divididos entre uma concentração de cafeeiros na área de colinas embutidas, na face Norte do interflúvio, onde as geadas são menos freqüentes (SILVEIRA, 1996), e em direção a jusante da unidade predominam as pastagens, entremeadas por algumas culturas temporárias pouco mecanizadas.

Esse compartimento abriga um conjunto de pequenas propriedades rurais produtoras de café que ainda resistem, perante aos novos modelos atuais de exploração rural. E este fato pode estar relacionado a duas importantes variáveis, a primeira que por a área possuir face Norte se torna menos propícia a ocorrência de geadas e em segundo, que os proprietários neste e em outros vários setores do município, são em sua maioria de idade avançada, o que lhes resguardam uma característica conservadora e pouco empresarial, sem perspectivas de inovação.

No topo predomina a presença do LATOSSOLO VERMELHO Distroférrico que avança até alguma ruptura de relevo ou quando esta não existe, até a média alta vertente, onde já se inicia a formação do NITOSSOLO VERMELHO Eutroférrico.

Nos sopés é possível encontrar NEOSSOLOS LITÓLICOS Eutróficos com exposição de blocos e/ou afloramentos rochosos, quando as declividades aumentam até a margem do rio ou na ausência do aumento da declividade, o NITOSSOLO VERMELHO avança até as margens dos cursos d'água, podendo inclusive apresentar alguns setores com hidromorfismo (Figura 4). 
FIGURA 4. 1- ROCHAS VULCÂNICAS ANDESI-BASÁLTICAS (PERÍODO JURO-CRETÁCEO FORMAÇÃO SERRA GERAL, GRUPO SÃO BENTO); 2- NEOSSOLO LITÓLICO EUTRÓFICO; 3NITOSSOLO VERMELHO EUTROFÉRRICO; 4- LATOSSOLO VERMELHO DISTROFÉRRICO; 5- NÍVEL DE ALTERAÇÃO (ALTERITA); 6- SUPERFÍCIE PIEZOMÉTRICA; 7- PASTAGENS; 8- BLOCOS EXPOSTOS; 9- NÍVEL DE BASE LOCAL; 10- ABACATEIROS; 11- CAFEEIROS.

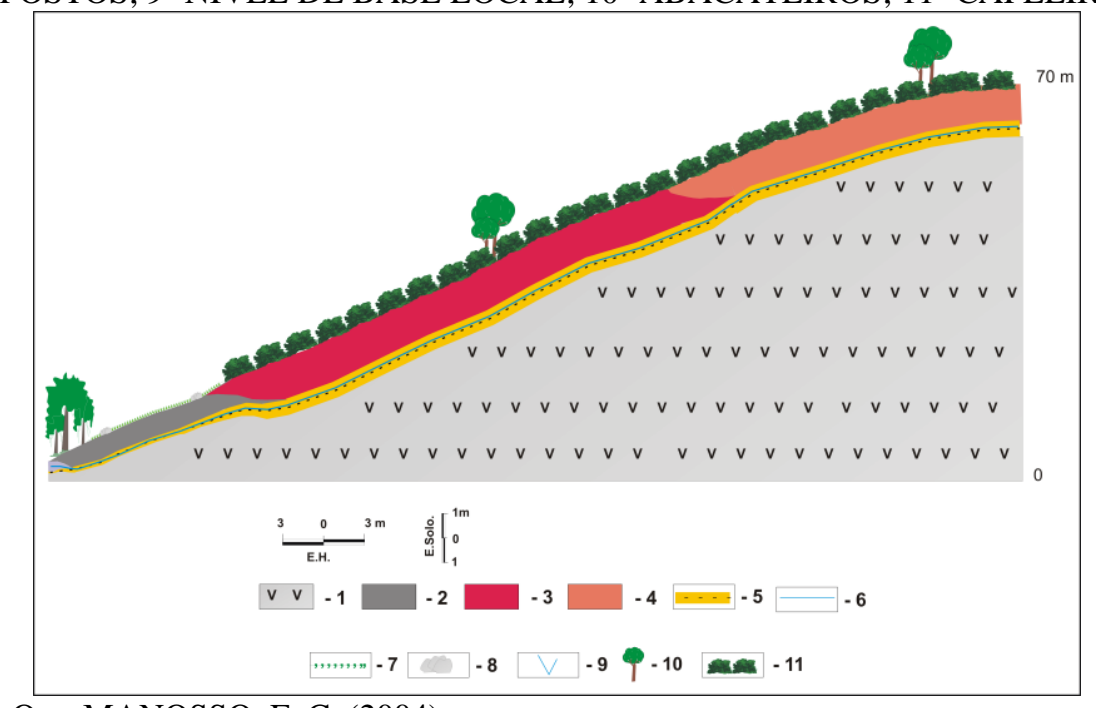

Org. MANOSSO, F. C. (2004)

A ocupação agrícola deste compartimento é definida principalmente pelos cafeeiros, que se situam desde os topos das vertentes até o início do terço inferior, onde o risco de geadas é maior no inverno e por isso o destino destas áreas são na maior parte para pastagens.

É comum entre os cafeeiros, sobretudo sobre as curvas de nível, o consórcio de plantio com arroz ou frutíferas como abacateiros, caquis e laranja, além da seqüência de grevíleas ao longo das estradas que descem perpendicularmente a vertente para prevenirem os efeitos eólicos sobre os cafeeiros e os solos.

Visto a proximidade da cidade, esta área ainda apresenta elevada população rural residente e um traço tradicional que remete épocas passadas.

\section{Compartimento 3 - "Foz do Ribeirão Dourados"}

Unidade de extensão restrita, mas com algumas particularidades em relação aos outros compartimentos. Apresenta-se como um conjunto de morros com vertentes convexas de declividades elevadas, recobertas por solos rasos (NEOSSOLOS LITÓLICOS) com afloramentos de blocos rochosos (matacões). Este compartimento é quase totalmente ocupado por pastagens, excetuando-se alguns setores de encostas com menor declividade, onde os 
solos são um pouco mais espessos (CHERNOSSOLO RÊNDZICO Lítico), sendo possível aí encontrar cultivos temporários de mecanização baixa e/ou inexistente.

É comum nestas áreas de predomínio de pastagens, como em outros setores do município (parte do C5 e C6) a baixa concentração de população rural, pois estas áreas são distantes da cidade, não apresentam infra-estrutura, como atendimento de saúde, escolas e comércio, além de que os acessos nem sempre são eficientes e práticos.

As vertentes são em geral convexo-retilínea no topo, seguida de uma pequena ruptura côncava, outro segmento retilíneo interrompido por um afloramento de rocha tendendo a côncavo na base.

Estas formas, que mostram influências estruturais, ligadas à níveis maciços mais espessos, alternados com níveis vesiculares e/ou amigdaloidais dos derrames vulcânicos, condicionam uma distribuição pedológica caracterizada pelo NEOSSOLO LITÓLICO Eutrófico no topo até o terço inferior da vertente e pelo CHERNOSSOLO RÊNDZICO Lítico pouco espesso no sopé e que muitas vezes sofre hidromorfismo em períodos úmidos.

Estes solos são sobrepostos a uma estreita faixa de alteração de rocha, que em alguns pontos aflora em superfície. Esta camada abriga a superfície piezométrica que pode oscilar bruscamente entre períodos sazonais diferentes, condicionando assim potenciais distintos ao longo da vertente, principalmente nas rupturas côncavas, onde o lençol pode apresentar-se de forma suspensa e propiciar erosões concentradas quando não há manejos corretos (Figura 5).

Com difícil mecanização agrícola devido as altas declividades e a grande exposição de blocos, este setor é predominantemente ocupado por pastagens, que abriga a criação de gado leiteiro e de corte.

\section{Compartimento 4 - "Colinas do Rio Bom"}

Localizada no extremo Sul do município e de pequena extensão, esta unidade se compõe de algumas colinas de topos aplainados, vertentes convexo-côncavo-retilíneas, em geral de declividades baixas. A declividade só se acentua em alguns setores de encostas, na baixa vertente, que estão relacionadas aos cursos d'água de primeira ordem. 
FIGURA 5. 1- ROCHAS VULCÂNICAS ANDESI-BASÁLTICAS (PERÍODO JURO-CRETÁCEO FORMAÇÃO SERRA GERAL, GRUPO SÃO BENTO); 2- NEOSSOLO LITÓLICO EUTRÓFICO; 3CHERNOSSOLO RÊNDZICO LÍTICO; 4- HIDROMORFISMO (GLEYS E PSEUDOGLEYS); 5- NÍVEL DE ALTERAÇÃO (ALTERITA); 6- SUPERFÍCIE PIEZOMÉTRICA; 7- PASTAGENS; 8- BLOCOS EXPOSTOS; 9- NÍVEL DE BASE LOCAL.

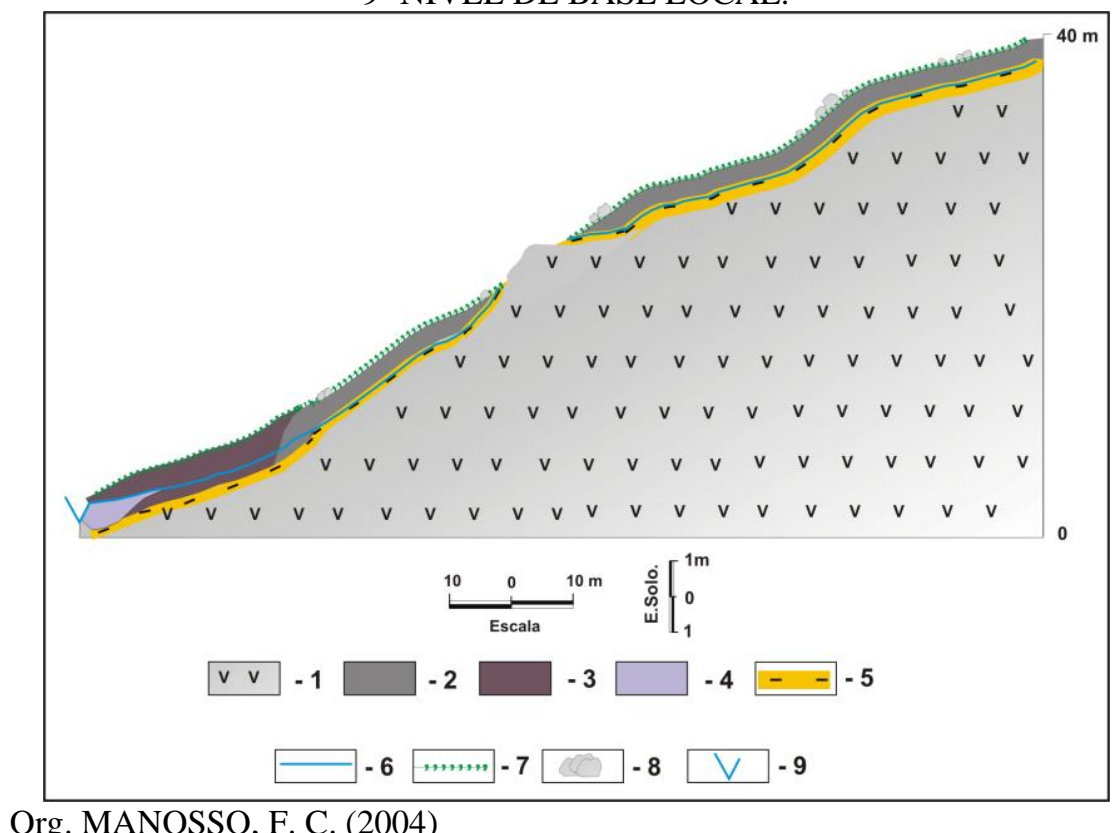

Org. MANOSSO, F. C. (2004)

Usos predominantemente com culturas temporárias, mecanizadas, trinômio soja, milho e trigo, configuram a paisagem, além de resquícios de vegetação original alterada, alguns reflorestamentos e pastagens, sobretudo sobre os solos rasos dos setores de encostas de maior declividade.

No topo do divisor principal entre o córrego do Ouro, ribeirão Cambira e o rio Bom é possível encontrar os LATOSSOLOS VERMELHOS Eutroférricos e nos conjuntos de encostas convexo-côncavo-retilíneas aparecem associações de NITOSSOLO VERMELHO Eutroférrico chernossólico mais os CHERNOSSOLOS ARGILÚVICOS.

A fisionomia padrão das vertentes do Compártimento 4 está composta por um setor convexo no topo e de declividade mais elevada que caracteriza os platôs embutidos. Nestas áreas ocorre solo raso como o NEOSSOLO LITÓLICO Eutrófico, com exposição de pequenos blocos rochosos e seguindo em direção ao sopé passa-se por um segmento levemente côncavo, com declividades fracas, onde existe o NITOSSOLO VERMELHO Eutroférrico que pode avançar até a margem do rio ou dar lugar ao aparecimento de CHERNOSSOLOS RÊNDZICO Lítico, que podem aparecer com frequência devido as condições de clima, topografia e interferência das oscilações freqüentes do nível piezométrico regulado pelo Rio Bom. 
Nos topos mais acidentados e com exposição de pequenos blocos rochosos aparece as pastagens e no restante da vertente, sobretudo devido as excelentes qualidades pedológicas é normal o predomínio de culturas temporárias mecanizadas, identificadas basicamente pelo milho, trigo e soja.

As oscilações do nível piezométrico também podem ocorrer com mais freqüência na ruptura existente entre a passagem dos solos rasos no topo para os solos mais espessos como o NITOSSOLO, onde a vertente pode apresentar setores côncavos, condicionando o aparecimento de olhos d'água no período chuvoso. E isso revela que estas áreas são instáveis e merece atenção no que se refere a instalação de processos erosivos (Figura 6).

Figura 6. 1- Rochas vulcânicas andesi-basálticas (Período Juro-Cretáceo - Formação Serra Geral, Grupo São Bento); 2- NEOSSOLO LITÓLICO Eutrófico; 3- NITOSSOLO VERMELHO Eutroférrico; 4CHERNOSSOLO RÊNDZICO Lítico; 5- Nível de Alteração (Alterita); 6- Superfície Piezométrica; 7 Pastagens; 8- Blocos expostos; 9- Nível de Base Local; 10- Culturas Temporárias (trigo em estágio inicial).

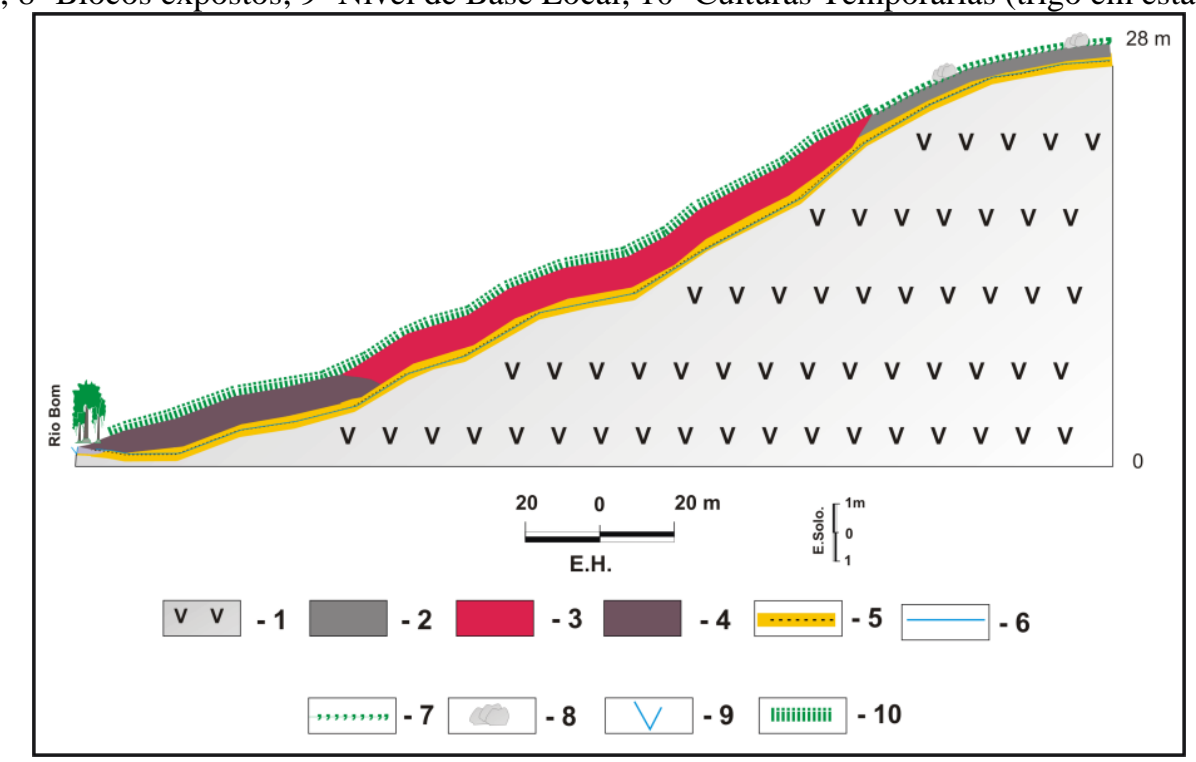

Org. MANOSSO, F. C. (2004)

\section{Compartimento 5 - "Vales do Setor Sul"}

Limítrofe com o compartimento 1, esta unidade representa uma continuidade dos vales dos cursos d'água que nascem nos bordos do platô principal (C1). Trata-se de uma unidade de paisagem constituída por vales encaixados, apresentando encostas com rupturas de declividades convexas acentuadas na alta vertente, marcadas muitas vezes por afloramentos 
de rocha, e rupturas côncavas na média a baixa vertente, desenvolvendo a jusante setores retilíneos curtos.

As vertentes apresentam declividades elevadas próximo às cabeceiras de drenagem dos ribeirões Cambira, Barra Nova e Biguaçu, e na área de confluência do ribeirão Biguaçu com o Barra Nova.

Relacionada a essa morfologia ocorre uma cobertura pedológica composta por uma área restrita de LATOSSOLOS VERMELHOS nos topos e uma grande extensão de NEOSSOLOS LITÓLICOS Eutróficos, da alta até a média vertente, que passam aos CHERNOSSOLOS RÊNDZICOS Líticos nos setores retilíneos da média e baixa encosta.

Essa área aparece ocupada predominantemente por pastagens, com algumas culturas permanentes, como frutíferas e cafeeiros, e raras culturas sazonais mecanizadas, estas últimas, aproveitando os setores de menor declividade e de maior espessura de solo.

As vertentes no Compartimento 5 estão condicionadas ao aparecimento de um pequeno setor com LATOSSOLO VERMELHO Distroférrico no topo, no entanto pouco espesso, podendo ser ocupado por lavouras temporárias ou cafeeiros. Enquanto que a passagem do topo para a alta vertente caracteriza-se por uma ruptura de elevada declividade com exposição de pequenos e médios blocos rochosos. Para jusante domina o NEOSSOLO LITÓLICO Eutrófico e os usos são preferencialmente constituídos por pastagens.

O terço inferior, muitas vezes é identificado por concavidades que condicionam a presença do CHERNOSSOLO RÊNDZICO Lítico, que ora está ocupado por pastagens, ora por pequenos setores de culturas temporárias de baixa mecanização agrícola (Figura 7).

É interessante salientar um fato verificado no campo, após uma seqüência de dias chuvosos que os últimos 40 metros no sentido montante para a jusante da vertente, o solo estava encharcado de água, ou seja, o nível piezométrico encontrava-se aflorando na superfície.

Estas condições representam uma série de limitações frente aos modos de exploração econômica destas áreas e isso deve ser verificado, como é o caso destas rupturas e destes afloramentos esporádicos de lençol freático que podem apresentar problemas de ordem estrutural caso sejam ocupados de forma errônea. 
FIGURA 7. 1- ROCHAS VULCÂNICAS ANDESI-BASÁLTICAS (PERÍODO JURO-CRETÁCEO FORMAÇÃO SERRA GERAL, GRUPO SÃO BENTO); 2- NEOSSOLO LITÓLICO EUTRÓFICO; 3-

LATOSSOLO VERMELHO DISTROFÉRRICO; 4- CHERNOSSOLO RÊNDZICO LÍTICO; 5HIDROMORFISMO (GLEYS E PSEUDOGLEYS); 6- SUPERFÍCIE PIEZOMÉTRICA; 7- NÍVEL DE ALTERAÇÃO (ALTERITA); 8- PASTAGENS; 9- BLOCOS EXPOSTOS; 10- DIREÇÃO DO ESCOAMENTO HÍDRICO SUPERFICIAL; 11- CULTURAS TEMPORÁRIAS (TRIGO EM ESTÁGIO INICIAL); 12CAFEEIROS.

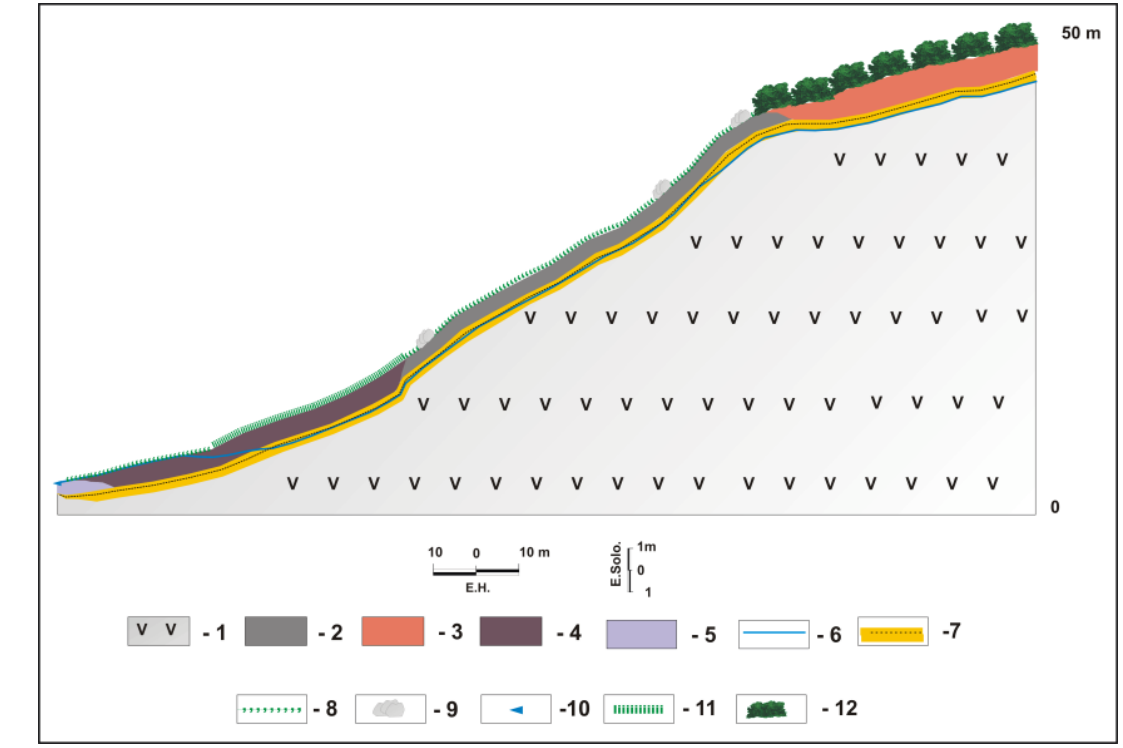

Org. MANOSSO, F. C. (2004)

\section{Compartimento 6 - "Vales do Setor Leste”}

Da mesma forma que o compartimento 5, com cotas altimétricas muito próximas e uma situação geomorfológica similar, mas situado a leste do compartimento 1, esta unidade de paisagem corresponde à continuidade dos esporões que partem do platô principal, aqui rebaixados e estreitos.

Ao contrário do que se observa nas outras unidades de paisagem nos limites com o compartimento 1, as declividades são menos acentuadas, tornando, desta forma, a transição do C1 para o C6 menos abrupta o que implica, também, em maior dificuldade para a sua delimitação. As declividades mais acentuadas (> 20\%), nesta unidade, aparecem em setores mais a jusante das bacias de drenagem.

As culturas temporárias (trigo, soja, milho), pouco mecanizadas, ocorrem preferencialmente em setores retilíneos na média e baixa vertente, sobre uma associação de CHERNOSSOLOS ARGILÚVICOS e/ou NITOSSOLOS VERMELHOS Eutroférricos. Nas áreas de topos estreitos recobertos pelo Latossolo Vermelho aparecem também algumas culturas temporárias ao lado de culturas permanentes (café). Os setores de alta a média 
vertente, onde ocorrem NEOSSOLOS LITÓLICOS preferencialmente, estão em geral ocupados por pastagem (Figura 8).

As vertentes do Compartimento 6 estão organizadas da seguinte forma: os topos dos interflúvios são bastante estreitos e planos, os solos são rasos (NEOSSOLO LITÓLICO Eutrófico). Apresentam rupturas marcadas na passagem para a alta vertente, seguidos de um segmento retilíneo com declividades fortes, onde há exposição de blocos e/ou afloramentos rochosos e a cobertura pedológica organiza-se com a ocorrência do NEOSSOLO LITÓLICO.

A base desse segmento é caracterizada pelo setor retilíneo, após uma ruptura côncava que se estende até o sopé, os solos variam entre o NITOSSOLO VERMELHO Eutroférrico e o CHERNOSSOLO RÊNDZICO Lítico / Argilúvico (Figura 8).

FIGURA 8. 1-ROCHAS VULCÂNICAS ANDESI-BASÁLTICAS (PERÍODO JURO-CRETÁCEO FORMAÇÃO SERRA GERAL, GRUPO SÃO BENTO); 2- NEOSSOLO LITÓLICO EUTRÓFICO; 3CHERNOSSOLO RÊNDZICO LÍTICO; 4- HIDROMORFISMO (GLEYS E PSEUDOGLEYS); 5- NITOSSOLO VERMELHO EUTROFÉRRICO; 6- NÍVEL DE ALTERAÇÃO (ALTERITA); 7- SUPERFÍCIE PIEZOMÉTRICA; 8- PASTAGENS; 9- BLOCOS EXPOSTOS; 10- NÍVEL DE BASE LOCAL; 11- MATA CILIAR.

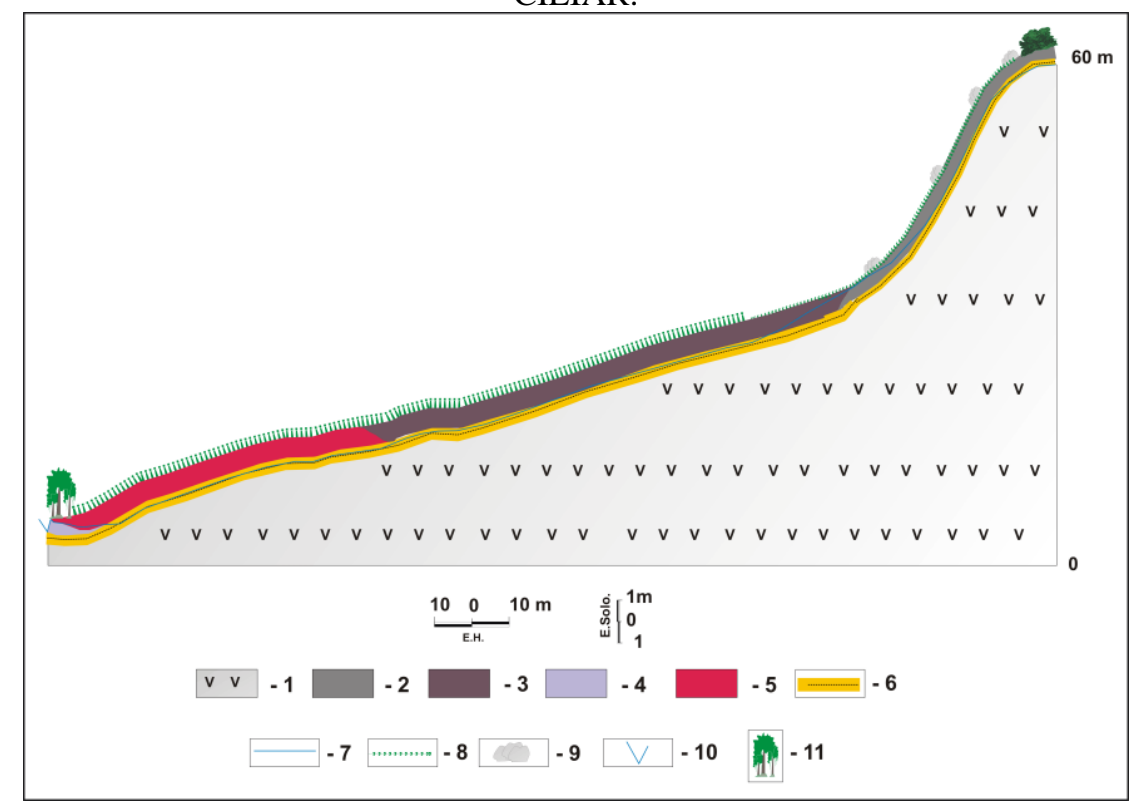

Org. MANOSSO, F. C. (2004)

Nos setores de solos rasos predomina a utilização por pastagens enquanto que sobre os solos mais espessos, onde as declividades são menores ocorre em maior quantidade as culturas temporárias, sendo que quando estes setores são pouco extensos a mecanização é baixa ou quase inexistente. 
$\mathrm{Na}$ ruptura côncava que marca a passagem para a "rampa" de menor declividade geralmente ocorre o afloramento do nível piezométrico em alguns períodos, o que favorece a instalação de processos erosivos.

\section{Compartimento 7 - "Colinas do rio do Cerne”}

O compartimento 7 (C7) apresenta-se com características morfológicas e pedológicas semelhantes àquelas do compartimento 4 (C4). Corresponde aos setores inferiores das bacias de drenagem, junto às suas confluências com o rio do Cerne. Nesta área a morfologia predominante é de colinas mais baixas (500 - 650m de altitude), médias a amplas, com topos arredondados e vertentes convexas de fracas declividades e com raras rupturas.

Seus usos predominantes são as culturas temporárias mecanizadas, como a soja, milho e trigo, algumas permanentes como o café e frutíferas, que se desenvolvem sobre as vertentes tipicamente convexas recobertas pelos CHERNOSSOLOS ARGILÚVICOS e os NITOSSOLOS VERMELHOS Eutróficos.

As vertentes do Compartimento 7 se caracterizam por declividades fracas a médias, presença de solos espessos, como o LATOSSOLO VERMELHO Distroférrico e o NITOSSOLO VERMELHO Eutroférrico que ocupam o topo e a média e baixa vertente respectivamente.

Estes solos propiciam um predomínio de uma exploração agrícola direcionada aos cultivos temporários, mecanizados e que se dividem entre a soja, o milho e o trigo principalmente.

Nestas vertentes convexo-retilíneas, que caracterizam as colinas médias, feições de rupturas de relevo ou setores de declividades mais acentuada, bem como a exposição de blocos ou afloramentos são muito raros, o que condiciona uma homogeneidade na dinâmica hídrica estabelecida pelo nível piezométrico que dificilmente atinge a superfície (Figura 9). 
FIGURA 9. 1- ROCHAS VULCÂNICAS ANDESI-BASÁLTICAS (PERÍODO JURO-CRETÁCEO FORMAÇÃO SERRA GERAL, GRUPO SÃO BENTO); 2- LATOSSOLO VERMELHO DISTROFÉRRICO; 3- NITOSSOLO VERMELHO EUTROFÉRRICO; 4- NÍVEL DE ALTERAÇÃO (ALTERITA); 5- SUPERFÍCIE PIEZOMÉTRICA; 6- CULTURAS TEMPORÁRIAS (TRIGO EM ESTÁGIO INICIAL); 7- NÍVEL DE BASE LOCAL.

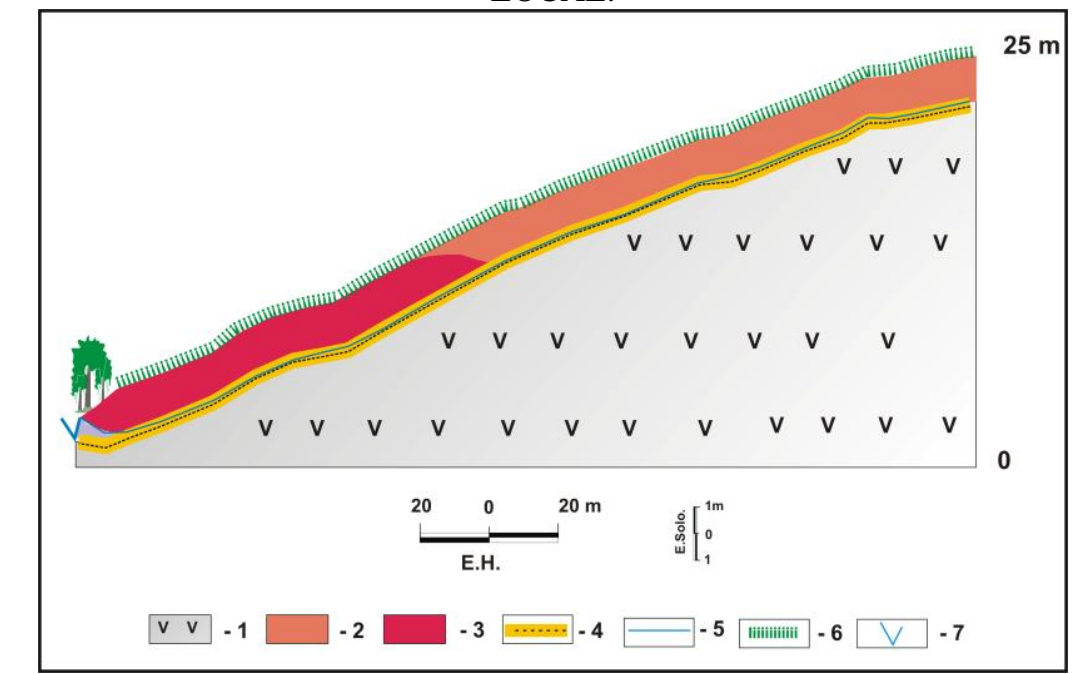

Org. MANOSSO, F. C. (2004)

\section{Síntese}

No intuito de sintetizar ou integrar as observações realizadas no campo e as informações coletadas junto aos órgãos especializados através de entrevistas e coleta de dados mais a ampla revisão bibliográfica, foi elaborado, a título de ilustração didática e final sobre a compartimentação da paisagem em questão, um mapa síntese (Figura 10).

Neste mapa (Figura 10) preocupou-se em mostrar a divisão dos compartimentos, indicar algumas relações que o município possui com o espaço regional em termos de fluxos, além das várias indicações localizadas através de simbologias, dos principais eventos e fenômenos que foram considerados significativos, em consequência da análise integrada realizada, de forma a refletir as principais diferenças de estrutura e funcionamento entre as unidades de paisagem identificadas no território municipal de Apucarana. 
FIGURA 10. SÍNTESE DAS UNIDADES DE PAISAGEM E PRINCIPAIS PROCESSOS DA ORGANIZAÇÃO DO ESPAÇO.

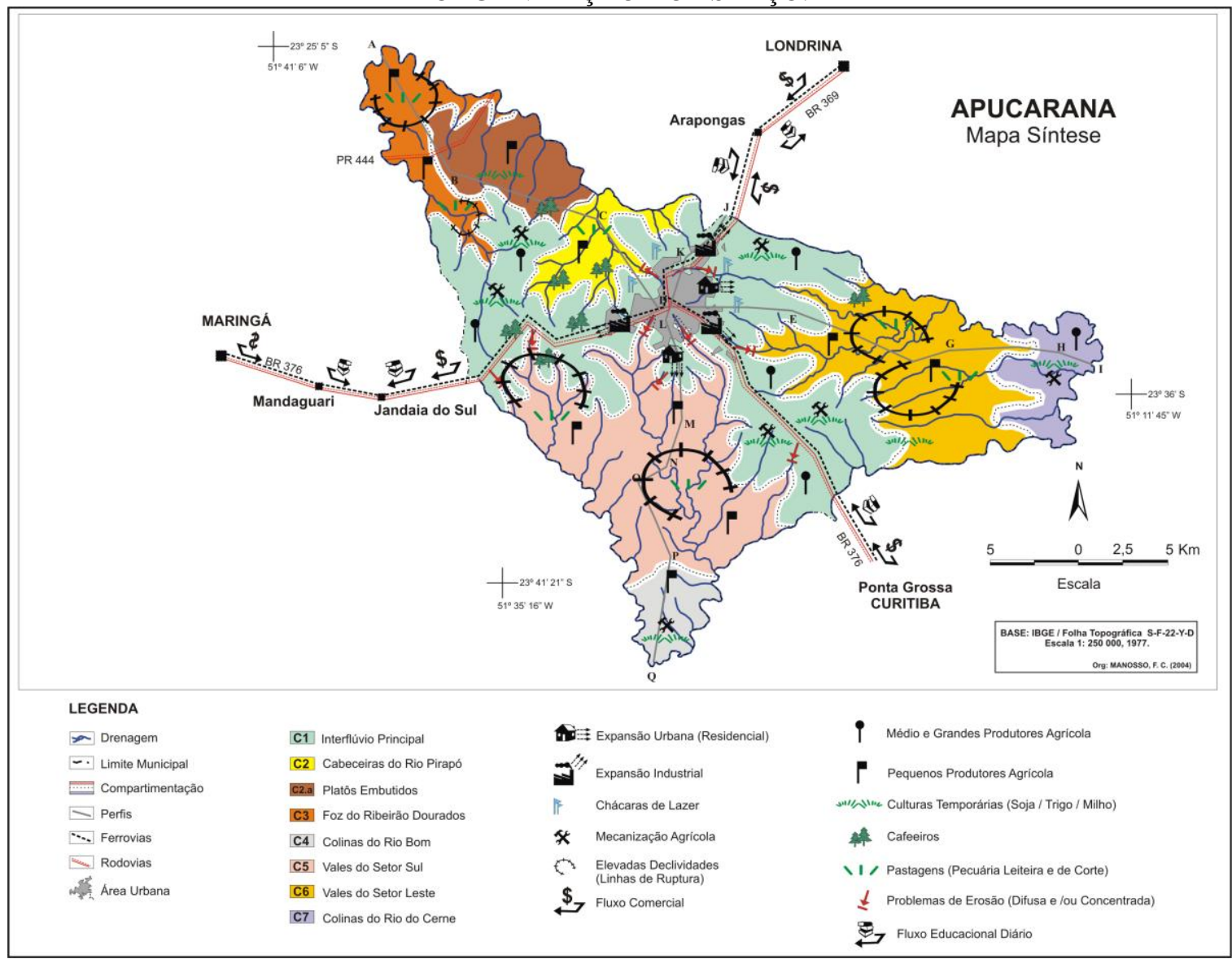

Em seguida, por meio de um quadro síntese (Quadro 2), é possível distinguir as principais características da variação horizontal e vertical da estrutura da paisagem, expressas pelas unidades de paisagem. 


\section{ISSN: 1981-089X}

Quadro 2. Quadro Síntese - As relações entre a estrutura geoecológica e a organização do espaço.

\begin{tabular}{|c|c|c|c|c|c|c|c|c|c|}
\hline \multirow{3}{*}{ UNIDADES } & \multicolumn{9}{|c|}{ ELE MENTOS DA PA ISA GEM } \\
\hline & \multirow[b]{2}{*}{ Geologia } & \multicolumn{2}{|c|}{ Clima } & \multirow[b]{2}{*}{ Pedologia } & \multirow[b]{2}{*}{ Relevo } & \multirow[b]{2}{*}{ Drenagem } & \multicolumn{3}{|c|}{ Sistema Socioeconômico } \\
\hline & & Temperatura & \begin{tabular}{|c|} 
Precipitaçã \\
o
\end{tabular} & & & & População & Exploração & $\begin{array}{c}\text { Pressões } \\
\text { Antropogênicas }\end{array}$ \\
\hline $\begin{array}{c}\text { C 1 } \\
\text { (Interflúvio } \\
\text { Principal) }\end{array}$ & $\begin{array}{l}\text { Derrames } \\
\text { vulcânicos } \\
\text { (basaltos). Linhas } \\
\text { de afloramentos na } \\
\text { passagem do C1 } \\
\text { para o C5 e C6. }\end{array}$ & $\begin{array}{l}\text { Médias anuais } \\
\text { entre } 19 \text { e } 20 \\
{ }^{\circ} \mathrm{C} \text {. Amplitude } \\
\text { térmica pouco } \\
\text { acentuada } \\
\text { (SILVEIRA, } \\
\text { 1987) Setor } \\
\text { mais elevado } \\
\text { exposto a } \\
\text { maior } \\
\text { frequiência de } \\
\text { ventos. }\end{array}$ & \begin{tabular}{|l} 
Zona de \\
transição \\
(SILVEIRA, \\
1987). \\
Médias de \\
acumulação \\
anual entre \\
1500 e 1700 \\
mm.
\end{tabular} & $\begin{array}{l}\text { LATOTOSSO } \\
\text { LO } \\
\text { VERMELHO } \\
\text { Distroférrico } \\
\text { nos topos e alta } \\
\text { vertente ao } \\
\text { longo do } \\
\text { interflúvio } \\
\text { principal. } \\
\\
\text { NITOSSOLO } \\
\text { VERMELHO } \\
\text { Eutroférrico } \\
\text { sobre as médias } \\
\text { vertentes. }\end{array}$ & $\begin{array}{l}\text { Cotas acima de } \\
800 \text { metros } \\
\text { associadas ao } \\
\text { interflúvio } \\
\text { principal, onde } \\
\text { predominam } \\
\text { vertentes } \\
\text { convexas } \\
\text { retilíneas de } \\
\text { declividades entre } \\
0 \text { a } 15 \% \text {. }\end{array}$ & $\begin{array}{l}\text { Área de } \\
\text { interflúvio que } \\
\text { abrange algumas } \\
\text { cabeceiras de } \\
\text { drenagem de } \\
\text { primeira ordem na } \\
\text { passagem para os } \\
\text { outros } \\
\text { compartimentos. }\end{array}$ & $\begin{array}{l}\text { Compartimento que } \\
\text { abriga toda } \\
\text { população urbana, } \\
\text { exceto de um } \\
\text { distrito e boa parte } \\
\text { da população rural } \\
\text { que reside em sua } \\
\text { maioria nas } \\
\text { cercanias da zona } \\
\text { urbana em chácaras } \\
\text { e pequenas } \\
\text { propriedades. }\end{array}$ & \begin{tabular}{|l} 
Abriga o uso \\
urbano (comercial, \\
residencial, \\
industrial e eixos \\
rodoviários) \\
Expansão \\
horizontal ee \\
direção aos C5, \\
C6 e C2. \\
Setor agrícola \\
mecanizado (soja, \\
milho e trigo). E \\
cafeeiros sobre o \\
C2 e sobre o \\
próprio interflúvio \\
principal ao longo \\
da BR 376.
\end{tabular} & 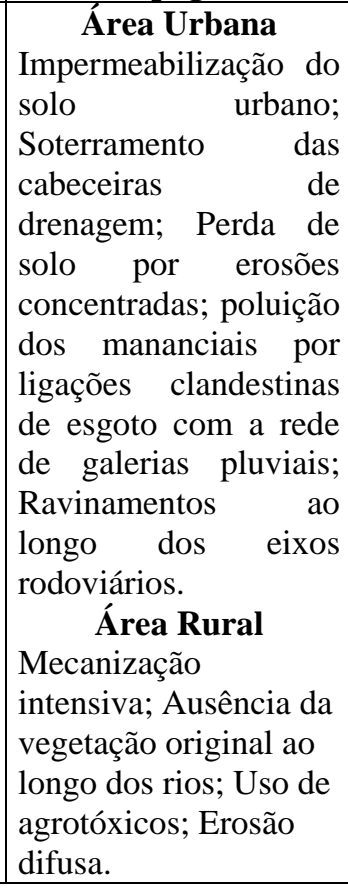 \\
\hline
\end{tabular}


Revista Geografar

Curitiba, v.3, n.2, p.86-116, jul./dez. 2008

\section{www.ser.ufpr.br/geografar}

\section{ISSN: 1981-089X}

\begin{tabular}{|c|c|c|c|c|c|c|c|c|c|c|}
\hline & $\begin{array}{c}\text { C 2.a } \\
\text { (Platôs } \\
\text { embutid } \\
\text { os) }\end{array}$ & \begin{tabular}{|l} 
Derrames \\
vulcânicos \\
(basaltos). \\
Afloramentos \\
sobre os pequenos \\
cursos d' água e \\
nas linhas de \\
ruptura das \\
vertentes \\
associadas a \\
exposição de \\
blocos \\
\end{tabular} & $\begin{array}{l}\text { Médias anuais } \\
\text { entre } 19 \text { e } 20 \\
{ }^{\circ} \mathrm{C} . \\
\text { Face norte. } \\
\text { Sofre maior } \\
\text { influencia da } \\
\text { massa tropical } \\
\text { continental. }\end{array}$ & $\begin{array}{l}\text { Médias de } \\
\text { acumulação } \\
\text { anual entre } \\
1500 \text { e } 1600 \\
\text { mm. }\end{array}$ & $\begin{array}{l}\text { NITOSSOLO } \\
\text { VERMELHO } \\
\text { Eutroférrico } \\
\text { podendo } \\
\text { ocorrer } \\
\text { NEOSSOLOS } \\
\text { LITÓLICOS } \\
\text { em rupturas ou } \\
\text { próximo aos } \\
\text { cursos d' água. }\end{array}$ & \begin{tabular}{|l|} 
Esporões de topos \\
restritos com cotas \\
entre 550 e 700 \\
metros, que se \\
alongam até o rio \\
Pirapó e formam \\
vertentes \\
convexas \\
retilíneas mais \\
restritas com \\
declividades entre \\
5 e $15 \%$. \\
\end{tabular} & $\begin{array}{l}\text { Pequenos } \\
\text { tributários de } \\
\text { primeira ordem, } \\
\text { perenes e } \\
\text { intermitentes que } \\
\text { deságuam } \\
\text { perpendicularment } \\
\text { e no rio Pirapó. }\end{array}$ & $\begin{array}{l}\text { Setor dotado de } \\
\text { inúmeras } \\
\text { habitações e infra- } \\
\text { estruturas } \\
\text { desmembradas da } \\
\text { antiga Fazenda } \\
\text { Ubatuba que } \\
\text { abrangia toda esta } \\
\text { unidade mais uma } \\
\text { parte do } \mathrm{C} 1 .\end{array}$ & $\begin{array}{l}\text { Cultivos } \\
\text { temporários } \\
\text { mecanizados nos } \\
\text { setores retilíneos } \\
\text { ou convexos e } \\
\text { pastagens sobre as } \\
\text { rupturas ou topos } \\
\text { estreitos com } \\
\text { afloramentos e } \\
\text { exposição de } \\
\text { blocos soltos. }\end{array}$ & $\begin{array}{l}\text { Ausência de vegetação } \\
\text { original ao longo dos } \\
\text { rios; uso de } \\
\text { agrotóxicos; erosão } \\
\text { difusa e concentrada. }\end{array}$ \\
\hline $\begin{array}{l}\mathrm{C} \\
\mathbf{2}\end{array}$ & $\begin{array}{c}\text { C 2.b } \\
\text { (Cabecei } \\
\text { ras do } \\
\text { Rio } \\
\text { Pirapó) }\end{array}$ & $\begin{array}{l}\text { Derrames } \\
\text { vulcânicos } \\
\text { (basaltos). } \\
\text { Afloramentos } \\
\text { sobre os pequenos } \\
\text { cursos d' água e } \\
\text { nas linhas de } \\
\text { Ruptura das } \\
\text { vertentes associado } \\
\text { a exposição de } \\
\text { blocos. }\end{array}$ & $\begin{array}{l}\text { Médias anuais } \\
\text { entre } 19 \text { e } 20 \\
{ }^{\circ} \mathrm{C} . \\
\text { Face norte } \\
\text { menos } \\
\text { propício a } \\
\text { geadas } \\
\text { (SILVEIRA, } \\
\text { 1987). }\end{array}$ & $\begin{array}{l}\text { Médias de } \\
\text { acumulação } \\
\text { anual entre } \\
1500 \text { e } 1600 \\
\text { mm. } \\
\text { Aumenta a } \\
\text { pluviosidade } \\
\text { em direção a } \\
\text { jusante } \\
\text { (SILVEIRA, } \\
\text { 1987). }\end{array}$ & $\begin{array}{l}\text { NITOSSOLO } \\
\text { VERMELHO } \\
\text { Eutroférrico } \\
\text { sobre o } \\
\text { conjunto de } \\
\text { colinas } \\
\text { embutidas ao } \\
\text { C1. }\end{array}$ & $\begin{array}{l}\text { Pequenas colinas } \\
\text { embutidas ao } \mathrm{C} 1 \\
\text { com cotas entre } \\
600 \text { e } 750 \text { metros } \\
\text { que configuram } \\
\text { um mosaico de } \\
\text { vertentes } \\
\text { convexas e de } \\
\text { declividades entre } \\
15 \text { a } 20 \% \text {. }\end{array}$ & $\begin{array}{l}\text { Tributários } \\
\text { formadores do rio } \\
\text { Pirapó associados } \\
\text { a cursos } \\
\text { intermitentes } \\
\text { entremeados ao } \\
\text { mosaico de } \\
\text { vertentes } \\
\text { embutidas ao } \mathrm{C} 1 .\end{array}$ & $\begin{array}{l}\text { Pequenas } \\
\text { propriedades } \\
\text { familiares } \\
\text { produtoras de café } \\
\text { ainda sob traços } \\
\text { típicos do período } \\
\text { de colonização. } \\
\text { Algumas pastagens } \\
\text { sobre sopés mais } \\
\text { inclinados ou } \\
\text { rupturas de relevo. }\end{array}$ & $\begin{array}{l}\text { Uso urbano sobre } \\
\text { as cabeceiras de } \\
\text { drenagem do rio } \\
\text { Pirapó. } \\
\text { Exploração } \\
\text { agrícola dominado } \\
\text { por pequenas } \\
\text { propriedades } \\
\text { familiares, } \\
\text { produtoras de café } \\
\text { intercaladas com a } \\
\text { subsistência nas } \\
\text { linhas de ruptura } \\
\text { (pastagens e } \\
\text { habitações). }\end{array}$ & $\begin{array}{l}\text { Ausência de vegetação } \\
\text { original ao longo dos } \\
\text { rios; Ravinamentos na } \\
\text { passagem para o C1; } \\
\text { Movimentos em massa } \\
\text { do solo nas áreas } \\
\text { declivosas (linhas de } \\
\text { ruptura e sopés). }\end{array}$ \\
\hline
\end{tabular}


Revista Geografar

Curitiba, v.3, n.2, p.86-116, jul./dez. 2008

\section{www.ser.ufpr.br/geografar}

\section{ISSN: 1981-089X}

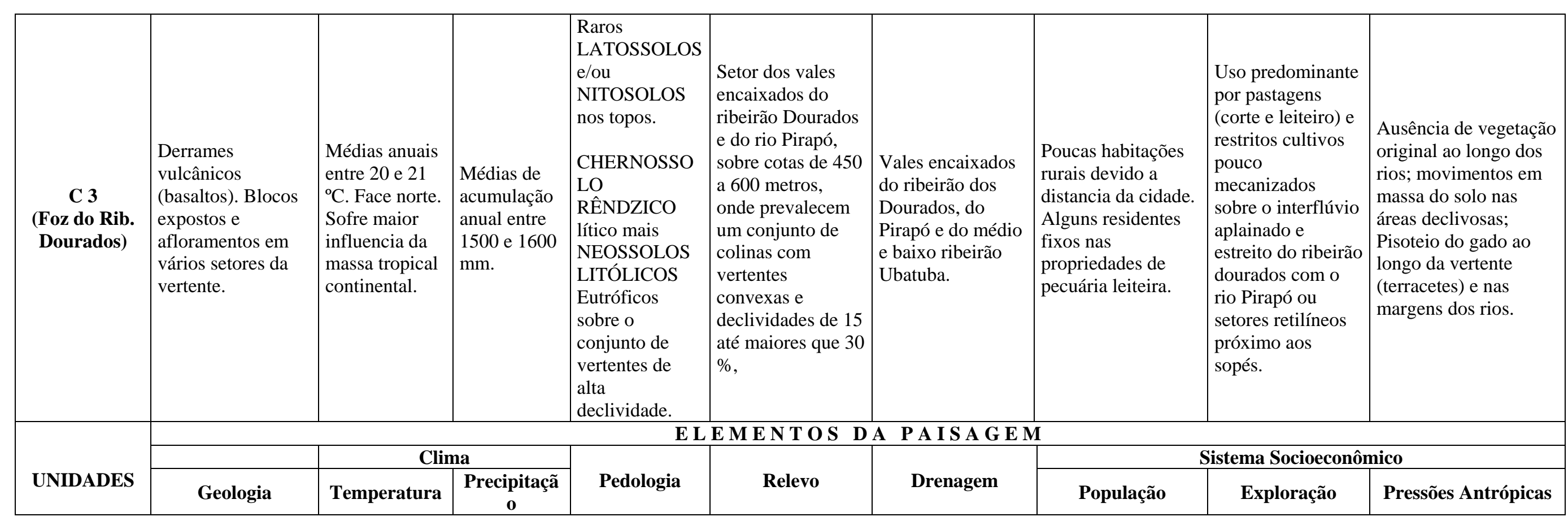




\section{Revista Geografar}

Curitiba, v.3, n.2, p.86-116, jul./dez. 2008

\section{www.ser.ufpr.br/geografar}

\section{ISSN: 1981-089X}

Médias anuais

Derrames

vulcânicos

(basaltos).

C 4 Afloramentos

(Colinas do

Rio Bom)

somente

sobre o leitos dos

cursos d' água e

em algumas

rupturas.

\section{entre 18 e 19}

Face sul com

influencia da

massa polar -

acentuada

amplitude

térmica e mais

propício a

geadas

(SILVEIRA,

1987).

\begin{tabular}{|c|c|c|}
\hline & & \\
\hline Restrita área de & & \\
\hline LATOSSOLO & & \\
\hline VERMELHO & & \\
\hline Distroférrico na & Vale aberto do rio & \\
\hline $\begin{array}{l}\text { condição de } \\
\text { topo. }\end{array}$ & $\begin{array}{l}\text { Bom sobre cotas } \\
\text { de } 500 \text { e } 650\end{array}$ & \\
\hline Associação & metros que & $\begin{array}{l}\text { Pequenos cursos } \\
\text { de primeira ordem }\end{array}$ \\
\hline CHERNOSSO & convexas de & tributários do \\
\hline $\begin{array}{l}\text { LOS } \\
\text { ARGILÚVICO }\end{array}$ & declividades entre & córrego do Ouro, \\
\hline mais & $\begin{array}{l}0 \text { e } 10 \%, \text { exceto } \\
\text { em aloumas linhas }\end{array}$ & $\begin{array}{l}\text { ribeirão Cambira e } \\
\text { rio Bom }\end{array}$ \\
\hline NEOSSOLOS & de ruptura onde as & \\
\hline $\begin{array}{l}\text { LITÓLICOS } \\
\text { Eutroficos e }\end{array}$ & declividades & \\
\hline NITOSSOLO & ultrapassam $25 \%$. & \\
\hline VERMELHO & & \\
\hline $\begin{array}{l}\text { Eutroférrico } \\
\text { chernossólico }\end{array}$ & & \\
\hline
\end{tabular}

Poucas habitações

rurais devido a

distância da cidade.

(propriedades

mecanizadas)
Exploração

agrícola

mecanizada (soja

trigo e milho) na

colinas suaves

intercaladas com

pastagens que

ocupam os vales

encaixados ou as

rupturas existentes

na passagem para

o C5.
Ausência de vegetação original ao longo dos

rios; Uso de

agrotóxicos;

Deslocamentos de

massa Movimentos em

massa do solo nas

reas declivosas

linhas de ruptura na

passagem para o C5); 
Revista Geografar

Curitiba, v.3, n.2, p.86-116, jul./dez. 2008

\section{SSN: 1981-089X}

\begin{tabular}{|c|c|c|c|c|c|c|c|c|c|}
\hline $\begin{array}{c}\text { C } 5 \\
\text { (Vales do } \\
\text { setor sul) }\end{array}$ & $\begin{array}{l}\text { Derrames } \\
\text { vulcânicos } \\
\text { (basaltos). Blocos } \\
\text { expostos mais } \\
\text { afloramentos em } \\
\text { linhas de rupturas } \\
\text { do } \\
\text { relevo que ocorrem } \\
\text { próximo aos sopés } \\
\text { e aos topos. }\end{array}$ & $\begin{array}{l}\text { Médias anuais } \\
\text { entre } 18 \text { e } 19 \\
{ }^{\circ} \mathrm{C} . \\
\text { Face sul com } \\
\text { influencia da } \\
\text { massa polar - } \\
\text { mais propício } \\
\text { a geadas } \\
\text { (SILVEIRA, } \\
\text { 1987). }\end{array}$ & $\begin{array}{l}\text { Médias de } \\
\text { acumulação } \\
\text { anual entre } \\
1600 \text { e } 1700 \\
\text { mm. }\end{array}$ & $\begin{array}{l}\text { CHERNOSSO } \\
\text { LO } \\
\text { RÊNDZICO } \\
\text { lítico mais } \\
\text { NEOSSOLOS } \\
\text { LITÓLICOS } \\
\text { Eutróficos } \\
\text { sobre as áreas } \\
\text { de forte } \\
\text { declividade. } \\
\\
\text { Restritos } \\
\text { LATOSSOLOS } \\
\text { VERMELHOS } \\
\text { Distroférricos } \\
\text { nos topos. }\end{array}$ & \begin{tabular}{|l} 
Conjunto de \\
esporões estreitos \\
que se alongam a \\
partir do C1 com \\
cotas entre 550 e \\
700 metros \\
formando \\
vertentes \\
convexas \\
retilíneas dotadas \\
de rupturas \\
côncavas em \\
posições variadas \\
na vertente. \\
Declividades entre \\
5 a $15 \%$ nos \\
topos e suas \\
extensões e entre \\
20 a maiores que \\
$30 \%$ nos vales \\
encaixados.
\end{tabular} & $\begin{array}{l}\text { Vales encaixados } \\
\text { dos ribeirões Barra } \\
\text { Nova, Cambira, } \\
\text { Biguaçu, Tuela e } \\
\text { do Ouro. }\end{array}$ & $\begin{array}{l}\text { Nas propriedades } \\
\text { de cultivos } \\
\text { permanentes } \\
\text { associados a } \\
\text { plantios } \\
\text { temporários em } \\
\text { alguns setores } \\
\text { ainda resistem } \\
\text { moradias rurais, no } \\
\text { entanto, nas } \\
\text { propriedades de } \\
\text { predomínio de } \\
\text { pastagens a } \\
\text { população residente } \\
\text { é muito restrita. }\end{array}$ & $\begin{array}{l}\text { Uso urbano sobre } \\
\text { as cabeceiras e os } \\
\text { anfiteatros } \\
\text { formadores dos } \\
\text { ribeirões Barra } \\
\text { Nova e Biguaçu } \\
\text { (passagem C1 } \\
\text { para o C5). } \\
\text { Explorações } \\
\text { agrícolas } \\
\text { temporárias e } \\
\text { mecanizadas sobre } \\
\text { os esporões } \\
\text { estreitos que } \\
\text { avançam em } \\
\text { direção sul mais o } \\
\text { domínio das } \\
\text { pastagens sobre os } \\
\text { vales de } \\
\text { declividades altas. }\end{array}$ & \begin{tabular}{l}
$\quad$ Área Urbana \\
Ocupação intensiva \\
sobre áreas declivosas \\
e de cabeceiras \\
(poluição e \\
canalização de parte \\
dos ribeirões Barra \\
Nova e Biguaçu). \\
\multicolumn{1}{c}{ Área Rural } \\
Ausência de vegetação \\
original ao longo dos \\
rios; Uso de \\
agrotóxicos; \\
Movimentos em massa \\
do solo nas áreas \\
declivosas (linhas de \\
ruptura); \\
Susceptibilidade \\
erosiva nas áreas de \\
lençóis suspensos.
\end{tabular} \\
\hline
\end{tabular}


Revista Geografar

Curitiba, v.3, n.2, p.86-116, jul./dez. 2008

\section{SSN: 1981-089X}

\begin{tabular}{|c|c|c|c|c|c|c|c|c|c|}
\hline $\begin{array}{c}\text { C } 6 \\
\text { (Vales do } \\
\text { setor leste) }\end{array}$ & $\begin{array}{l}\text { Derrames } \\
\text { vulcânicos } \\
\text { (basaltos). Blocos } \\
\text { expostos mais } \\
\text { afloramentos em } \\
\text { linhas de rupturas } \\
\text { do } \\
\text { relevo que ocorrem } \\
\text { próximo aos topos } \\
\text { e sopés. }\end{array}$ & $\begin{array}{l}\text { Médias anuais } \\
\text { entre } 20 \text { e } 21 \\
{ }^{\circ} \mathrm{C} \text {. Insolação } \\
\text { diferenciada } \\
\text { (bacias com } \\
\text { escoamento } \\
\text { em direção } \\
\text { leste). Elevada } \\
\text { amplitude } \\
\text { térmica entre } \\
\text { topos e sopés } \\
\text { (SILVEIRA, } \\
\text { 1987) }\end{array}$ & $\begin{array}{l}\text { Médias de } \\
\text { acumulação } \\
\text { anual entre } \\
1500 \text { e } 1700 \\
\text { mm. }\end{array}$ & $\begin{array}{l}\text { LATOSSOLOS } \\
\text { VERMELHOS } \\
\text { Distroférrico } \\
\text { sobre o avanço } \\
\text { dos esporões } \\
\text { estreitos e } \\
\text { aplainados. } \\
\text { Associação } \\
\text { CHERNOSSO } \\
\text { LOS } \\
\text { ARGILÚVICO } \\
\text { mais } \\
\text { NEOSSOLOS } \\
\text { LITÓLICOS } \\
\text { Eutroficos e } \\
\text { NITOSSOLO } \\
\text { VERMELHO } \\
\text { Eutroférrico } \\
\text { chernossólico } \\
\text { sobre as } \\
\text { declividades } \\
\text { altas. } \\
\text { NITOSSOLO } \\
\text { VERMELHO } \\
\text { eutroférrico } \\
\text { sobre as } \\
\text { declividades } \\
\text { médias. }\end{array}$ & $\begin{array}{l}\text { Vales encaixados } \\
\text { entre esporões } \\
\text { estreitos que } \\
\text { avançam no } \\
\text { sentido leste } \\
\text { dotados de } \\
\text { vertentes } \\
\text { convexas } \\
\text { retilíneas entre } \\
\text { rupturas côncavas } \\
\text { em posições } \\
\text { variadas na } \\
\text { vertente. } \\
\text { Cotas entre } 500 \text { e } \\
750 \text { metros, onde } \\
\text { as declividades } \\
\text { variam entre } 5 \text { e } \\
10 \% \text { nos topos } \\
\text { estreitos e } \\
\text { apresentam-se } \\
\text { mais acentuada } \\
\text { sobre os vales ( } 20 \\
\text { até maiores que } 30 \\
\% \text { ). }\end{array}$ & $\begin{array}{l}\text { Vales encaixados } \\
\text { do baixo ribeirão } \\
\text { da Raposa, alto } \\
\text { ribeirão do Cerne, } \\
\text { ribeirão } \\
\text { Pinhalzinho, } \\
\text { Clementino e } \\
\text { Jacucaça. }\end{array}$ & $\begin{array}{l}\text { Algumas } \\
\text { propriedades que } \\
\text { assimilam cultivos } \\
\text { permanentes e/ou } \\
\text { temporários } \\
\text { associados as } \\
\text { pastagens garantem } \\
\text { a residência fixa, } \\
\text { enquanto que } \\
\text { propriedades de } \\
\text { domínio das } \\
\text { pastagens não } \\
\text { abrigam residentes } \\
\text { fixos. }\end{array}$ & $\begin{array}{l}\text { Áreas residenciais } \\
\text { recentes próximo } \\
\text { as nascentes dos } \\
\text { formadores do } \\
\text { ribeirões do Cerne } \\
\text { e da Raposa. } \\
\text { Restritos plantios } \\
\text { temporários de } \\
\text { pouca ou } \\
\text { inexistente } \\
\text { mecanização } \\
\text { sobre os platôs ou } \\
\text { setores retilíneos } \\
\text { ligado as } \\
\text { pastagens que } \\
\text { recobrem as áreas } \\
\text { declivosas dos } \\
\text { vales ou de suas } \\
\text { linhas de rupturas }\end{array}$ & \begin{tabular}{l}
\multicolumn{1}{c}{$\quad$ Área Urbana } \\
Bairros residenciais de \\
classe baixa (carência \\
de infra-estrutura, \\
como rede de esgoto); \\
Erosões concentradas \\
nos limites com o C1; \\
\multicolumn{1}{c}{ Área Rural } \\
Ausência da cobertura \\
vegetal original; \\
Movimentos em massa \\
do solo nas áreas \\
declivosas (linhas de \\
ruptura); Uso de \\
agrotóxicos; \\
Susceptibilidade \\
erosiva nas áreas de \\
lençóis suspensos.
\end{tabular} \\
\hline
\end{tabular}


Revista Geografar

Curitiba, v.3, n.2, p.86-116, jul./dez. 2008

\section{www.ser.ufpr.br/geografar}

ISSN: 1981-089X

\begin{tabular}{|c|c|c|c|c|c|c|c|c|c|}
\hline $\begin{array}{c}\text { C } 7 \\
\text { (Colinas do } \\
\text { Rio do Cerne) }\end{array}$ & $\begin{array}{l}\text { Derrames } \\
\text { vulcânicos } \\
\text { (basaltos). } \\
\text { Afloramentos } \\
\text { somente } \\
\text { sobre o leito dos } \\
\text { cursos d' água. }\end{array}$ & $\begin{array}{l}\text { Médias anuais } \\
\text { entre } 20 \text { e } 21 \\
{ }^{\circ} \mathrm{C} \text {. Insolação } \\
\text { diferenciada. }\end{array}$ & $\begin{array}{l}\text { Médias de } \\
\text { acumulação } \\
\text { anual entre } \\
1500 \text { e } 1600 \\
\text { mm. }\end{array}$ & $\begin{array}{l}\text { NITOSSOLO } \\
\text { VERMELHO } \\
\text { eutroférrico } \\
\text { sobre as } \\
\text { declividades } \\
\text { médias. } \\
\text { CHERNOSSO } \\
\text { LO } \\
\text { ARGILÚVICO } \\
\text { mais } \\
\text { NEOSSOLOS } \\
\text { LITÓLICOS } \\
\text { eutróficos sobre } \\
\text { as vertentes } \\
\text { declivosas. }\end{array}$ & $\begin{array}{l}\text { Unidade das } \\
\text { colinas convexas } \\
\text { do vale aberto do } \\
\text { rio do Cerne com } \\
\text { cotas entre } 450 \text { e } \\
600 \text { metros e de } \\
\text { declividades entre } \\
0 \text { e } 15 \% \text {. }\end{array}$ & $\begin{array}{l}\text { Vale aberto onde } \\
\text { os ribeirões } \\
\text { Pinhalzinho, } \\
\text { Clementino e } \\
\text { Jacucaça } \\
\text { encontram o } \\
\text { ribeirão do Cerne. }\end{array}$ & $\begin{array}{l}\text { Poucas habitações } \\
\text { rurais devido a } \\
\text { distância da cidade. } \\
\text { (propriedades } \\
\text { mecanizadas) }\end{array}$ & $\begin{array}{l}\text { Plantios } \\
\text { temporários } \\
\text { mecanizados } \\
\text { (soja, milho e } \\
\text { trigo) sobre o } \\
\text { conjunto de } \\
\text { colinas suaves do } \\
\text { vale aberto do } \\
\text { ribeirão do Cerne. }\end{array}$ & $\begin{array}{l}\text { Carência de cobertura } \\
\text { vegetal original nas } \\
\text { margens dos rios; uso } \\
\text { de agrotóxicos; } \\
\text { Deslocamentos e perda } \\
\text { de material nas } \\
\text { rupturas (passagem } \\
\text { para C6) }\end{array}$ \\
\hline
\end{tabular}




\section{CONSIDERAÇÕES FINAIS}

A aplicação do método da análise integrada da paisagem sobre o território municipal de Apucarana levou a perceber que:

- a adoção de um recorte político como o município para um estudo de paisagem também é eficiente. Ao longo dessa unidade territorial, ficou evidente a existência de um mosaico de paisagens diferentes, com particularidades específicas da sua estrutura geoecológica e que desse modo, precisam ser pensadas de forma particularizada para o seu uso, ocupação e exploração mais racional e sustentável;

- cada unidade de paisagem identificada, conforme varia a sua estrutura vertical, varia também a sua fisionomia, refletindo horizontalmente as condições distintas para o uso do solo. Isso fica bastante evidente nas vertentes típicas de cada compartimento, onde, sobretudo a cobertura pedológica, exposição de rocha e profundidade do nível freático pode limitar determinados tipos de uso;

- a integração das características físicas, econômicas e sociais desse mosaico de paisagens, por meio do mapa e quadro síntese, permitiu visualizar que o recorte municipal é uma unidade de funcionamento do sistema socioeconômico, o qual age sobre um sistema físico dinâmico.

\section{REFERÊNCIAS}

BEROUCHACHVILI, N. E BERTRAND, G. O Geossistema ou "Sistema Territorial Natural”. Revue Géographie dês Pyrenées et du Sud-ouest, 49 (2), Toulouse, 1978. p. 167 180.

BERTRAND, G. La Science du Paysage, une science diagonale. Revue Géographique des Pyrénées et du Sud-Ouest, Tome 18, 1972, p. 127 - 133.

BERTRAND, G. Le paysage entre la nature et la societé. In Revue Géographique des Pyrénées et du Sud-Ouest, 49 (2), 1978, p. 239 - 258.

BERTRAND, G. Paysage et Géographie Physique Globale, Esquise et Méthodologie. Revue Géographique des Pyrénées et du Sud-Ouest, n. 49, 1978, p. 16 - 26.

BERTRAND, G. Las estructuras naturals del epacio geográfico, el exemplo de las Montañas Cantábricas Centrales (NW de España) In Geografía Física y Paisaje 
(Traducción de Trabajos del Prof. Georges Bertrand) Departamento de Geografía, Facultad de Geografía e História - Universidade de Salamanca, 1981.

BOLOS, M. Manual de Ciencia del Paisaje, Teoria, Métodos y Aplicaciones, Barcelona: Alev, 1992. 273p.

BUCHE, W. M. Caracterização geoagroambiental do município de Londrina, PR a partir de uma visão sistêmica. (Dissertação de Mestrado) - Universidade Estadual de Maringá Departamento de Geografia, Maringá, 2003.

CARVAlHO, P. F. E BRAGA, R. (Orgs.) Perspectivas de Gestão Ambiental em cidades médias. UNESP - IGCE, Rio Claro: DEPLAN, 2001. 183p.

CAVALHEIRO, F., RUEDA, J. R. J. E JESUS, N. de. Compartimentação do meio físico da área da Serra do Japi - Jundiaí (SP) em zonas de fragilidade quanto à degredação. GEOUSP - Espaço e Tempo, n. 11, São Paulo, 2002, p. 85 - 100.

DESCHAMPS, M. V. Vulnerabilidade Socioamebiental na região metropolitana de Curitiba. Tese de Doutorado - Programa de Pós-Graduação em Meio Ambiente e Desenvolvimento, UFPR, Curitiba, 2004.

DIAS, J. A Construção da Paisagem na Raia Divisória São Paulo - Paraná - Mato Grosso do Sul: um estudo por teledetecção. (Tese de Doutorado), Presidente Prudente: UNESP/FCT, 2003. 267p.

DIAS, J. e SANTOS L. A paisagem e o geossistema como possibilidade de leitura da expressão do espaço sócio-ambiental rural. Confins, Número 1, 2 semestre 2007. Disponível em: http://confins.revues.org/document10.html\#texte. Consultado em 25-02-2009.

ESPINO, E. P. Ciência del Paisaje y Planes de Ordenación Territorial. In Congresso de Ciencia del Paisaje, 2 (Bell - Lloc, septiembre, 1994), Monografies de L' Equip 6, Barcelona. 1995.

FERREIRA, M. C. Mapeamento de Unidades de Paisagem em Sistemas de Informação Geográgica: Alguns pressupostos fundamentais. Geografia, v. 22 n. 1, Rio Claro: abril 1997. p. $24-35$.

FRADES, M. A. Tradición y Cambio en el Paisaje Zamorano - La Campiña de la Guareña. Instituto de Estudios Zamoranos, Universidad de León: 1994. 489p.

FREITAS, M. W. D. de. E CUNHA, S. B. da. Fisiologia da Paisagem e Geossistemas: Contribuições Metodológicas integradoras do pensamento geográfico. In X Simpósio Brasileiro de Geografia Física Aplicada, Rio de Janeiro, 2003.

KRÖKER, R. Unidades de Paisagem no bairro Santa Felicidade / Curitiba-PR na escala 1:10000 com base na hemorobia. Revista Eletrônica Geografar, v. 2, Curitiba, 2007, p 6666.

MARÇAL, M. dos S. e LUZ, L. M. da. Geomorfologia aplicada a classificação de unidade de paisagem na bacia do rio Macaé - Litoral Fluminense. In Simpósio Brasileiro de Geografia Física Aplicada, 10, Rio de Janeiro, 2003. 
MONTEIRO, C. A. F. Geossistemas: a história de uma procura. São Paulo: Contexto, 2000. 127 p.

MONTEIRO, C. A. F. Os Geossistemas como elemento de integração na síntese geográfica e fator de promoção interdisciplinar na compreensão do ambiente. Aula Inaugural proferida no Curso de Doutorado Interdisciplinar em Ciências Humanas - Sociedade e Meio Ambiente, UFSC, 8 de março de 1995.PARANÁ, - Instituto de terras, cartografia e florestas, Atlas do Estado do Paraná 1987.

OLIVEIRA, D. A. de. Ecologia e Valoração da Paisagem no entorno da cidade de Paranaguá. Dissertação (Mestrado), Programa de Pós-Gradualção em Engenharia Floresal Universidade Federal do Paraná, Curitiba, 2003. Disponível em: http://dspace.c3sl.ufpr.br:8080/dspace/handle/1884/2217. Consultado em 25-02-2009.

PECCIOLI FILHO, R. C. Planejamento da Paisagem na bacia hidrográfica do rio Palmital , região metropolitana de Curitiba-PR. Dissertação de Mestrado - Programa de Pós-Graduação em Geografia (Mestrado e Doutorado), UFPR, Curitiba, 2005, 115p.

PEDROTTI, F. e MARTINELLI, M. A cartografia das unidades de paisagem: questões metodológicas. Revista do Departamento de Geografia (USP), 14, São Paulo, 2001. p. 39 46.

PELLERIN, J. e HELLVIN, M. Análise Estrutural e Organização das paisagens: as pesquisas visando a generalização cartográfica. In Congresso de Ciência do Solo, 21, Anais... Campinas, 1998. p. 455 - 463.

RIBEIRO, A. R. S.; BÄHR, P. H. e CENTENO, S. J. Integração de imagens de satélite e dados complementares para a delimitação de unidades de paisagem usando uma abordagem baseada em regiões. Boletim de Ciências Geodésicas, v. 8, n. 1, UFPR, Curitiba, 2002. p. 47 - 57.

RICHARD, J. F. Paysages, Écosystémes, Environnement: une approche géographique. O.R.S.T.O.M., Collection de Réference, 1975. Disponível em: http://www.bondy.ird.fr/pleins_textes/. Consultado em: 08/2003.

RICHARD, J. F. e BEROUTCHACHIVILI, N. L. Vers l'elaboration d'un systéme d'information sur les paysages du monde. Cab. Sei. Hum, 32 (4), 1996. p. 823 - 842. Disponível em: http://www.bondy.ird.fr/pleins_textes/. Consultado em: 09/

RODRIGUES, J. M. Conferencia: La Ciência del Paisaje a luz del Paradigma Ambiental. Geonotas, v.2, n. 1, 1998. Disponível em: www.dge.uem.br/geonotas. Consultado em: $08 / 2003$.

RODRIGUEZ, M. M. J.; MAURO, A. C.; RUSSO, L. I.; SILVA, S. M. C.; BOVO, R.; ARCURI, P. E. M. e MARINHO, F. L. V. Análise da Paisagem como base para uma estratégia de organização geoambiental: Corumbataí (SP). Geografia, v. 20 (1), Rio Claro, 1995. p. 81 - 129.

ROSS, J. L. S. Geomorfologia, Ambiente e Planejamento. São Paulo: Contexto, 1991. 85p.

ROSSI, M. e QUEIROZ NETO, J. P. Relações solo / paisagem em regiões tropicais úmidas: o exemplo da Serra do Mar em São Paulo, Brasil. Revista do Departamento de Geografia (USP), 14, São Paulo, 2001. p. 11 - 23. 
RUHOFF, A. L. Diagnóstico Ambiental do município de sinimbu (RS): a ação dos agentes transformadores na construção da paisagem. GEOGRAFARES, n. 3 (jun), Vitória-ES, 2002. p. 57-67.

SANTOS, J. E. E PIRES, J. S. R. (Edts) Estudos integrados em Geossistemas - Estação Ecológica de Jataí, v. 1, São Carlos: RIMA, 2000. 345 p.

SCHEIBE, F. L. O município como Geossistema: uma visão integradora, Geosul, v. 12, n. 23, Florianópolis $-1^{\circ}$ Semestre, 1997. p. 46 -55.

SILVEIRA, M. L. As condicionantes climáticas e a organização do espaço rural no setor sudeste do Planalto de Apucarana, PR. (Dissertação de Mestrado), v. 1, Presidente Prudente, 1996.

SISTEMA METEOROLÓGICO DO ESTADO DO PARANÁ (SIMEPAR), Série de Dados de Temperatura, Precipitação e Umidade relativa da estação climatológica do município de Apucarana - PR, (1968 - 2002).

VALASKI, S. e NUCCI, J. C. Comparação entre a classificação de unidades de paisagem e a lei de zoneamento e uso do solo do bairro boqueirão, Curitiba/PR. Anais do XII SBGFA, v. 1, Natal, 2007, p 1-15.

(Recebido em fevereiro/09. Aceito em março/09) 